\title{
Mercury speciation and exchanges at the air-water interface of a tropical artificial reservoir, French Guiana
}

\author{
B. Muresan ${ }^{1}$, D. Cossa*, S. Richard**, B. Burban ${ }^{\star \star}$ \\ *Institut français de recherche pour l'exploitation durable de la mer (IFREMER), BP 21105, F.44311 Nantes cedex \\ 3, France (EU) \\ **HYDRECO, Laboratoire de Petit-Saut, BP 823, F.97388 Kourou, French Guiana (EU) \\ *: Corresponding author : Tel.: 336846054 46; Email: bogdan1977@free.fr
}

\begin{abstract}
:
The distribution and speciation of mercury $(\mathrm{Hg})$ in air, rain, and surface waters from the artificial tropical lake of Petit-Saut in French Guiana were investigated during the 2003/04 period. In the air, total gaseous mercury (TGM) at the dam station averaged $12 \quad 2$ pmol m-3 of which $>98 \%$ was gaseous elemental mercury (GEM). GEM distribution depicted a day-night cycling with high concentrations (up to $15 \mathrm{pmol} \mathrm{m}-3$ ) at dawn and low concentrations (down to $5 \mathrm{pmol} \mathrm{m}-3$ ) at nightfall. Reactive gaseous mercury (RGM) represented $<1 \%$ of the GEM with a mean concentration of 43 fmol m-3. Diel RGM variations were negatively related to GEM. In the rain, the sum of all $\mathrm{Hg}$ species in the unfiltered (HgTUNF) averaged $16 \quad 12$ pmol L-1. Temporal distribution of HgTUNF exhibited a pattern of high concentrations during the late dry seasons (up to $57.5 \mathrm{pmol}$ L-1) and low concentrations (down to $2.7 \mathrm{pmol} \mathrm{L}-1$ ) in the course of the wet seasons. Unfiltered reactive (HgRUNF), dissolved gaseous (DGM) and monomethyl (MMHgUNF) Hg constituted 20, 5 and $5 \%$ of HgTUNF, respectively. All measured $\mathrm{Hg}$ species were positively related and displayed negative relationships with the $\mathrm{pH}$ of the rain. In the reservoir surface waters, dissolved total mercury (HgTD) averaged 3.4 1.2 pmol L-1 of which $10 \%$ consisted of DGM. DGM showed a trend of high concentrations during the dry seasons (480 $270 \mathrm{fmol} \mathrm{L-1})$ and lower (230 $130 \mathrm{fmol} \mathrm{L-1}$ ) in the course of the wet seasons. Diel variations included diurnal photo-induced DGM production (of about $60 \mathrm{fmol}$ L-1 h-1) coupled to minute to hour oxidation / reduction cycles (of $>100 \mathrm{fmol} \mathrm{L-1}$ amplitude). Finally, calculated atmospheric $\mathrm{Hg}$ inputs to the Petit-Saut reservoir represented 14 moles yr-1 whereas DGM evasion reached 23 moles yr-1. Apportionment among forms of $\mathrm{Hg}$ deposition indicated that up to $75 \%$ of the total $\mathrm{Hg}$ invasive flux follows the rainfall pathway.
\end{abstract}

Keywords: Atmosphere; Artificial reservoir; Mercury; Speciation; Fluxes 


\section{Introduction}

Divalent inorganic mercury $\left(\mathrm{Hg}^{\prime \prime}\right)$ in natural surface waters can either be methylated and transferred to the aquatic food webs or, alternatively, be reduced to elemental mercury $\left(\mathrm{Hg}^{\circ}\right)$ and then evolve into the air. Thus, the rate of reduction is of fundamental importance, since this reaction would restrict the quantity of divalent $\mathrm{Hg}^{\prime \prime}$ available for bioaccumulation and auxiliary toxicity in predator animals and human consumers. Because of its high residence time ( 1 year), $\mathrm{Hg}$ is dispersed in the troposphere as gaseous elemental mercury (GEM) (Fitzgerald et al., 1991). However, in the last few years, accumulating evidence has shown that GEM is quickly oxidized as "reactive gaseous mercury" (RGM, presumably composed of $\mathrm{HgCl}_{2}$ ) in the atmosphere, leading to a rapid and intensive re-deposition on water surfaces (Lindberg and Stratton, 1998). Thus, to understand the processes and quantify the net exchange, $\mathrm{Hg}$ speciation in the atmosphere, as well as speciation in deposition, must be documented. A significant number of studies have provided such data in boreal, temperate and marine environments (e.g., Schroeder et al., 1998; Hedgecock and Pirrone, 2001, Mason and Sheu, 2001 Laurier et al., 2003), while few are available for tropical ecosystems.

The Sinnamary River in French Guiana is $250 \mathrm{~km}$ long. Its catchment area spans over $7000 \mathrm{~km}^{2}$ of crystalline formation overgrown by uninhabited primary forest. In the 1990s, the Sinnamary River was harnessed by the construction of the Petit-Saut hydroelectric dam circa $70 \mathrm{~km}$ upstream of the outlet to the Atlantic (Fig. 1). The resulting reservoir lake $\left(5^{\circ} 04^{\prime}\right.$ North, $53^{\circ} 03^{\prime}$ West) stretches over $60 \mathrm{~km}$ in length and width. The maximum water depth reaches $35 \mathrm{~m}$ and corresponds to the immersion of 350 $\mathrm{km}^{2}$ of uncleared forest (Huynh et al., 1997). According to Richard (1996), the development of such a neotropical water-body has brought about considerable changes in water quality and the natural $\mathrm{Hg}$ cycling of the basin of the Sinnamary River.

In the present work, we use the measured $\mathrm{Hg}$ concentrations and speciation in air, rain and surface water samples in combination with interfacial transportation models to: (i) examine the atmospheric cycling of $\mathrm{Hg}$ in the tropical region of the Sinnamary basin, (ii) describe $\mathrm{Hg}$ transformations in the surface waters of the neoformed Petit-Saut reservoir and, (iii) establish a mass balance calculation for $\mathrm{Hg}$ exchanges between the reservoir and the surrounding atmosphere. In a general way, the current study aims to demonstrate the role of the Petit-Saut reservoir as a source of elemental $\mathrm{Hg}$ for the atmosphere.

\section{Material and methods}

\subsection{Sample collection}

\subsubsection{Air sampling}

In the vicinity of the Petit-Saut dam, temporal distribution and speciation of atmospheric $\mathrm{Hg}$ were studied for nearly one year (2003-2004). Excepting the months of September and October 2003, total gaseous Hg (TGM) was uninterruptedly measured from April 2003 to April 2004. The TGM speciation was investigated from January 2004 to April 2004 and for a shorter period between November 2004 and January 2005. It was calculated as the sum of GEM and RGM (Table 1). Additional TGM samplings were made on April 2005 downstream from the outflow of the turbines in the vicinity of an artificial aeration system. Since the turbines are fed with water from the anoxic part of the reservoir, TGM measurements accounted for the partial degassing of discharged hypolimnetic waters during the aeration process.

\subsubsection{Rain sampling}

Wet deposition was collected at the HYDRECo field laboratory station about $200 \mathrm{~m}$ downstream from the dam (Fig. 1). Compiled data account for 20 months of regular sampling from April 2003 to December 2004. Samples for rainfall amount, conductivity, $\mathrm{pH}$ and occasionally total organic carbon (TOC) determinations were collected by means of a polyethylene bag. For $\mathrm{Hg}$, the collection system consisted of a $14 \mathrm{~cm}$ diameter Teflon (PTFE) funnel attached to a $500 \mathrm{~mL}$ acid-clean Teflon (FEP) bottle. A $16 \mathrm{~cm}$ long flute of Teflon (PTFE) gently drove the rainfall water directly from the base of the funnel to the bottom of the bottle. Samples were collected on a weekly basis using ultra-clean sampling techniques. The high precipitation (up to $150 \mathrm{~mm} \mathrm{hr}^{-1}$ ) rate allowed rapid collection of the necessary rain amount for analyses and thus limited the $\mathrm{Hg}$ photo-reduction and adsorption processes during the rain event (in the range of 5 to 10 minutes). Bottles were double bagged then frozen at -20 
${ }^{\circ} \mathrm{C}$ in dark conditions. Precipitation waters were analyzed for $\mathrm{HgT}_{\mathrm{UNF}}, \mathrm{HgR}_{\mathrm{UNF}}, \mathrm{DGM}$ and MMHgunF (see below for definitions).

\subsubsection{Surface water sampling}

Surface water samples were collected just below the air-water interface (AWI) by immersing an acid clean Teflon (FEP) bottle with a gloved hand (Fig. 1). Analyses of dissolved gaseous mercury (DGM) were performed within 2 hours of collection. The sum of all $\mathrm{Hg}$ species ( $\left.\mathrm{HgT}_{\mathrm{UNF}}\right)$ along with the dissolved $\left(\mathrm{HgT}_{\mathrm{D}}\right)$ and reactive $\left(\mathrm{HgR}_{\mathrm{UNF}}\right)$ fractions were processed the same day. Aliquots were kept to determine monomethylmercury (MMHg) in the unfiltered (MMHgunf), dissolved ( $\mathrm{MMHg}_{\mathrm{D}}$ ) and the particulate $\left(\mathrm{MMHg}_{\mathrm{P}}\right)$ phases. Water samples were filtered using hydrophilic Teflon membranes $(0.45$ $\mu \mathrm{m}$ pore size, $45 \mathrm{~mm}$ diameter, LCR ${ }^{\circledR}$, Millipore), then acidified with $0.5 \%(\mathrm{v} / \mathrm{v}) \mathrm{HCl}$ (Suprapur ${ }^{\circledR}$, Merck). Used filters (particulate samples) and corresponding filtered solutions were ultimately double bagged and stored at $-20^{\circ} \mathrm{C}$ in dark conditions until analysis.

\subsection{Sample analysis}

\subsubsection{Ancillary variables}

In the epilimnion, measurements for temperature, $\mathrm{pH}$, dissolved oxygen, conductivity and redox were determined in situ by means of an YSI multiparameter probe sonde 600XLM. Additional analyses for organic matter (OM) content, $\mathrm{pH}$ and conductivity in atmospheric wet deposition were carried out at the HYDRECO field laboratory. Total organic and inorganic carbon in the global and the dissolved fractions were analyzed by IR spectroscopy after oxidative or acidic digestion of the samples.

\subsubsection{Atmospheric gaseous mercury}

The analyzer systems included an automated Tekran Model 2537A, which was used together with a Model 1130 Speciation Unit to simultaneously monitor GEM and RGM in air. This instrumentation and its implementation are described in detail by Poissant et al. (2005). Briefly, the analytical train of the Tekran 2537A instrument is based on the amalgamation of gaseous $\mathrm{Hg}$ onto gold cartridges followed by a thermodesorption and analysis by cold vapor atomic fluorescence spectrophotometry. The Model 2537A provided 5-min GEM (part of TGM that passed through the Model 1130) analyses at sub-pmol $\mathrm{m}^{-3}$ levels. The analytical precision was estimated to be better than $2 \%$. During sampling, RGM in the atmosphere was captured in the Model $1130 \mathrm{KCl}$-coated quartz annular denuder module. The 1130 speciation unit was configured to collect 3 hour samples at a $10 \mathrm{~L} \mathrm{~min}^{-1}$ flow rate. After the 3 hour sampling period, the 1130 Speciation Unit was flushed with $\mathrm{Hg}$-free air, then RGM was thermodesorbed and analyzed. The denuders were biweekly reconditioned using the Tekran protocol (Tekran, 2001).

In 2005 , some air measurements were made in the vicinity of the aerators located at the tailrace (the downstream part of a dam where the impounded water re-enters the river) of the turbine where the TGM concentrations were high. We used a portable Hg analyzer RA-915+ (LUMEX) allowing us to get TGM data in a continuous mode with a detection limit of $10 \mathrm{pmol} \mathrm{m}^{-3}$. The RA-915+ $\mathrm{Hg}$ analyzer employs the atomic absorption spectrometry technique, which is implemented using the direct Zeeman Effect. No significant differences in the TGM concentrations were observed between both instruments, upon the condition of exceeding the RA-915+ detection limit.

\subsubsection{Mercury speciation in water and particles}

All $\mathrm{Hg}$ species in water samples were detected by cold vapor atomic fluorescence spectrometry (AFS). $\mathrm{HgT}$ was determined according to Bloom and Fitzgerald (1988), by the formation of volatile elemental $\mathrm{Hg}$ (released by $\mathrm{SnCl}_{2}$ reduction, after 30 minutes of acidic $\mathrm{BrCl}$ oxidation) and its preconcentration on a gold trap. $\mathrm{HgR}$ (the easily reducible fraction) was obtained by $\mathrm{pH} 1$ direct reduction with $\mathrm{SnCl}_{2}$. Unfiltered samples for DGM (mainly $\mathrm{Hg}^{0}$ ) analyses were sparged for 20 min with $\mathrm{Hg}$-free argon at 200 $\mathrm{mL} \mathrm{min}{ }^{-1}$. The detection limits, defined as 3.3 times the standard deviation on the blanks, were usually $0.05 \mathrm{pmol} \mathrm{L}^{-1}$ for the $\mathrm{HgT}$ and $\mathrm{HgR}$, and $25 \mathrm{fmol} \mathrm{L}^{-1}$ for DGM. The variation of five replicate samples was lower than $10 \%$. The accuracy for $\mathrm{HgT}$ determinations was regularly checked, using the reference material (ORMS-3) from the National Council of Canada as certified reference material (CRM). MMHg was determined in the unfiltered ( $\left.\mathrm{MMHg}_{\mathrm{unF}}\right)$ and dissolved ( $\left.\mathrm{MMHg}_{\mathrm{D}}\right)$ phases using the method proposed by Bloom (1989) and modified by Liang et al. (1994) and Leermarkers et al. (2001). 
The water samples were stored with $0.5 \%(\mathrm{v} / \mathrm{v}) \mathrm{HCl}$, which is a reliable method for a 3 week storage period (Parker and Bloom, 2005). MMHg in acidified water was extracted by $\mathrm{CH} 2 \mathrm{Cl} 2$ and then transferred into $40 \mathrm{~mL}$ of Milli-Q water by evaporating the organic solvent. The aqueous solutions were analyzed for $\mathrm{MMHg}$ by gas chromatography after ethylation and adsorption / desorption on a Tenax $®$ column. For particulate $\mathrm{HgT}(\mathrm{HgTP})$ and $\mathrm{MMHgP}$, an acidic dissolution (with concentrated $\mathrm{HCl} /$ HNO3) of the filtered particles took place before the procedures described previously. Detection limits were 0.01 pmol L-1 and 0.005 pmol g-1 for respectively a $100 \mathrm{~mL}$ water and $200 \mathrm{mg}$ solid sample. Precision was bellow $10 \%$ for all analyses. Using the available reference material (IAEA-405), the accuracy of the method was estimated to be better than $5 \%$ with $91 \pm 8 \%$ recovery. The detailed procedure is given by Cossa et al. (2002 and 2003).

\section{Tropospheric and surface water characteristics}

The Guianese seasonal pattern consists of four uneven periods: the short wet season (from the middle of November to the middle of February), the short summer of March, the long wet season (from April until July) and the long dry season (from the middle of August to the middle of November). The precipitations vary from $1700 \mathrm{~mm} \mathrm{yr}^{-1}$ in the Northwest to $3800 \mathrm{~mm} \mathrm{yr}^{-1}$ eastward of the Sinnamary basin. The annual recorded rainfall is $3000 \mathrm{~mm}$ on average on the shore line from Kourou to Cayenne and reaches $2500 \mathrm{~mm}$ on the regions inland. The average intensity of the precipitation is approximately $30-40 \mathrm{~mm} \mathrm{hr}^{-1}$ with a duration in the order of 5 to 10 minutes. Crests can exceed 150 $\mathrm{mm} \mathrm{hr} r^{-1}$ but the duration of such showers is approximately one minute (Meteo-France, weather reports).

Anthropogenic sources of atmospheric compounds are located along the shoreline and constitute the Guianese industry (e.g. the European Space Center), the car emissions and the biomass burning. Natural sources mainly consist of the Atlantic Ocean, the ferralitic soils and the overlying vegetation (Richard, 2001). In wet seasons, oceanic air masses spread over French Guiana: this source was apparent through sodium, sulfate and magnesium loaded aerosols (up to 50,8 and $5 \mathrm{nmol} \mathrm{m}$, respectively). In dry seasons, the intensification of slash-and-burn agriculture induces higher potassium, nitrates and oxalic acid levels (up to 10,5 and $0.9 \mathrm{nmol} \mathrm{m}^{-3}$, respectively). According to Richard (2001), in 1999, the acidity of rainfall significantly correlated with its measured organic acid content. Indeed, between the wet and the dry season of 1999, pH decreased from 5.2 to 4.9 concurrently to a doubling in oxalic and acetic acid concentrations. As a result the anthropic activity may define an important source of volatile organic acids to the local atmosphere including rain and aerosols.

Mean temperatures in the surface waters $(0.5 \mathrm{~m}$ depth) from the Petit-Saut reservoir and in the atmosphere for the $2003 / 04$ period were $29.7 \pm 0.6$ and $27.3 \pm 0.5^{\circ} \mathrm{C}$, respectively. $\mathrm{The} \mathrm{pH}(6.2 \pm 0.2$ vs $4.6 \pm 0.4$ units), conductivity (21.4 \pm 0.4 vs $\left.14 \pm 8 \mu \mathrm{S} \mathrm{cm}^{-1}\right)$ and TOC $(0.39 \pm 0.03$ vs $0.10 \pm 0.06$ $\mathrm{mmol} \mathrm{L}^{-1}$ ) were higher in the surface waters than in rain. In the surface waters, high conductivity (i.e. lowest pH: 5.9 units) depicted the dry seasons whereas low conductivity (i.e. highest pH: 6.5 units) corresponded to the wet seasons. Maxima in redox (Eh) were measured in the dry seasons $(340 \pm 20$ $\mathrm{mV})$ and minima in the wet seasons $(290 \pm 20 \mathrm{mV})$. According to Dumestre et al. (1999), the dry seasons correspond to high primary production periods and development of phytoplanktonic and phototrophic bacterial communities.

\section{Results}

\subsection{Mercury in air}

\subsubsection{Gaseous $\mathrm{Hg}$ speciation and distribution}

During the 2003/04 period, TGM at the HYDRECO laboratory station averaged $12 \pm 2 \mathrm{pmol} \mathrm{m}^{-3}$. This was similar to the mean North Atlantic level of $11.5 \mathrm{pmol} \mathrm{m}^{-3}$ measured by Slerm and Langer (1992). The GEM constituted more than $98 \%$ of TGM. Maxima of GEM concentrations were usually measured in wet seasons $\left(14.5 \mathrm{pmol} \mathrm{m}^{-3}\right)$ and minima in the dry seasons $\left(9.8 \mathrm{pmol} \mathrm{m}{ }^{-3}\right)$. Typically, GEM displayed a significant $(p \leq 0.05)$ increase with the percentage of rainfall excess $\left(r^{2}=0.45 ; n=11 \text { and [GEM] }\right]_{p m o l}$ $\mathrm{m}-3=0.03 \%$ Rain $_{\text {exce }}+12.3$ ). GEM depicted a regular day-night cycle with high concentrations (up 15 pmol m${ }^{-3}$ ) measured at dawn and low concentrations (down to $5 \mathrm{pmol} \mathrm{m}^{-3}$ ) at nightfall (Fig. 2). RGM represented less than $1 \%$ of GEM with a mean concentration of $4 \pm 3 \mathrm{fmol} \mathrm{m}^{-3}$. Measured 
concentrations varied from the apparatus limit detection (close to $0.05 \mathrm{fmol} \mathrm{m} \mathrm{m}^{-3}$ ) up to $180 \mathrm{fmol} \mathrm{m}$. The minimum of GEM, usually measured at nightfall, corresponded to a maximum of RGM in the atmosphere (Fig. 2).

The TGM measured downstream from the dam at the tailrace of the turbines ranged from below the detection limit of the LUMEX detector $\left(\sim 10 \mathrm{pmol} \mathrm{m}^{-3}\right)$ to $115 \mathrm{pmol} \mathrm{m}^{-3}$ and averaged $47 \pm 21 \mathrm{pmol} \mathrm{m}^{-3}$. Reaching the artificial aeration system, a vertical profile (from the AWI to $2 \mathrm{~m}$ height) of TGM was determined in order to probe the $\mathrm{Hg}$ volatilization from dam discharged waters (Fig. 3). Maxima of concentrations were measured at the AWI $\left(380 \pm 330 \mathrm{pmol} \mathrm{m}^{-3}\right)$ and showed a marked variability (from 95 to $1060 \mathrm{pmol} \mathrm{m}^{-3}$ ). Higher up, TGM levels underwent a pronounced decrease within the first centimeters: from $380 \pm 330$ to $120 \pm 20$ then $33 \pm 2 \mathrm{pmol} \mathrm{m}^{-3}$, respectively, at $A W I, 0.5$ and $1 \mathrm{~m}$ height. TGM concentrations also rapidly diminished with increasing distance from the artificial cascade constituting the aeration system (Fig. 3). At $1 \mathrm{~m}$ height, TGM decreased from $23 \pm 11$ to $13 \pm 4$ then < $10 \mathrm{pmol} \mathrm{m}^{-3}$ at 10,50 and $200 \mathrm{~m}$ distance from the aeration system. The low concentrations $(<10$ pmol m${ }^{-3}$ ) indicated that, at these locations and time of year, the plume gas evolved from the aerators was mostly diluted in the atmosphere.

\subsubsection{Mercury in the aerosols}

$\mathrm{HgT}_{\mathrm{P}}$ and $\mathrm{MMHg}_{\mathrm{p}}$ were measured in the atmospheric aerosols collected on $0.2 \mu \mathrm{m}$ Teflon filters from the Tekran 2537A analyzer. $\mathrm{HgT}_{\mathrm{P}}$ concentrations were 11800 and $4100 \mathrm{pmol} \mathrm{g}^{-1}$ (i.e. 0.046 and 0.012 pmol m${ }^{-3}$ ) with respect to the short dry (April 2003) and long wet (June 2004) seasons. MMHg concentrations (and methylated percentages) were $310(2.6 \%)$ and $10(0.3 \%) \mathrm{pmol} \mathrm{g}^{-1}$, respectively.

\subsection{Mercury in rain}

The monitoring of $\mathrm{HgT}_{\mathrm{UNF}}$ (Fig. 4) displayed a pattern of high concentrations in the late dry season (up to $57.5 \mathrm{pmol} \mathrm{L}^{-1}$, November 2004) and lower in the wet season (down to $2.7 \mathrm{pmol} \mathrm{L^{-1 }}$, March 2004). In the wet season, $\mathrm{HgT}_{\mathrm{UNF}}$ concentration in rain (84 rain events) averaged $16 \pm 12 \mathrm{pmol} \mathrm{L}^{-1}$ (Table 2). This was within the range of concentrations $\left(17.8 \pm 2.9 \mathrm{pmol} \mathrm{L}^{-1}\right)$ of the South and equatorial Atlantic environments measured by Lamborg et al. (1999). HgR UNF constituted approximately $20 \%$ of $\mathrm{HgT}_{\text {UNF. }}$. With concentrations varying from 0.1 to $20.8 \mathrm{pmol} \mathrm{L}^{-1}$, its temporal distribution revealed a positive correlation with that of $\mathrm{HgT}_{\mathrm{UNF}}\left(\mathrm{r}^{2}=0.54\right)$. The high temperature $\left(\mathrm{H}=466 \mathrm{~atm} \mathrm{~mol}{ }^{-1}\right.$ at $\left.28{ }^{\circ} \mathrm{C}\right)$ resulted in low DGM concentrations in rain $\left(800 \pm 900 \mathrm{fmol} \mathrm{L}^{-1}\right)$. DGM constituted $25 \%$ of HgR UNF (i.e. $5 \%$ of $\left.\mathrm{HgT}_{\mathrm{UNF}}\right)$ and displayed an analogous temporal distribution to $\mathrm{HgR}_{\mathrm{UNF}}\left(\mathrm{r}^{2}=73\right)$ and therefore $\mathrm{HgT}\left(\mathrm{r}^{2}=\right.$ 0.42 ). Regarding MMHgunF, concentrations varied from 0.05 to $10.2 \mathrm{pmol} \mathrm{L}^{-1}$ with a mean value of 0.8 pmol L-1. This was in the high range of values found in the literature $\left(0.2-0.8 \mathrm{pmol} \mathrm{L}^{-1}\right.$; Bloom and Watras, 1989; Mason et al., 1997; Lawson and Mason, 2001; Hall et al., 2005). Despite its variability, MMHguNF showed significant positive correlations with $\mathrm{HgT}_{\mathrm{UNF}}\left(\mathrm{r}^{2}=0.39\right), \mathrm{HgR}_{\mathrm{UNF}}\left(\mathrm{r}^{2}=0.52\right)$ and DGM $\left(r^{2}=0.59\right)$. MMHg UNF concentrations also increased with acidity in rain $\left(r^{2}=0.52\right)$.

\subsection{Mercury in surface waters}

\subsubsection{In situ Hg speciation}

$\mathrm{HgT}_{\mathrm{UNF}}$ in the uppermost $0.5 \mathrm{~m}$ of the reservoir averaged $4.5 \pm 1.8 \mathrm{pmol} \mathrm{L}^{-1}$ of which $75 \%(3.4 \pm 1.2$ pmol L ${ }^{-1}$ ) was dissolved. The particulate phase represented $1.1 \pm 0.9 \mathrm{pmol} \mathrm{L}^{-1}$ (i.e. $7 \pm 6 \mathrm{mg} \mathrm{L}^{-1}$ of SPM at $230 \pm 190 \mathrm{pmol} \mathrm{g}^{-1}$ of $\mathrm{HgT}_{\mathrm{P}}$ ). Maxima of $\mathrm{HgT}_{\text {UNF }}$ (up to $5.5 \mathrm{pmol} \mathrm{L}^{-1}$ ) were measured during the runoff periods of the short wet seasons. Stations from the ancient Sinnamary riverbed had the highest HgT concentrations: $5.2 \pm 1.7,3.8 \pm 1.0$ and $1.4 \pm 0.9$ (i.e. $270 \pm 230 \mathrm{pmol} \mathrm{g}^{-1}$ ) pmol L $\mathrm{L}^{-1}$, respectively, for $\mathrm{HgT}_{\mathrm{UNF}}, \mathrm{HgT}_{\mathrm{D}}$ and $\mathrm{HgT}_{\mathrm{P}}$. MMHguNF at the AWI occupied $15 \%\left(0.6 \pm 0.3 \mathrm{pmol}^{-1}\right)$ of the $\mathrm{HgT}_{\mathrm{UNF}}$ and respectively reached $0.3 \pm 0.1$ and $0.3 \pm 0.2$ (i.e. $130 \pm 80 \mathrm{pmol} \mathrm{g}^{-1}$ ) pmol $\mathrm{L}^{-1}$ in the dissolved and particulate phases. Unlike $\mathrm{HgT}$, maxima of $\mathrm{MMHguNF}_{\mathrm{N}}$ concentrations occurred during the high productivity period of the dry season (up to $0.9 \pm 0.2 \mathrm{pmol} \mathrm{L}^{-1}$ ). $\mathrm{MMHg}_{\mathrm{unF}}$ positively correlated with $\operatorname{MMHg}_{\mathrm{P}}\left(\mathrm{r}^{2}=0.84 ;\left[\mathrm{MMHg}_{\mathrm{UNF}}\right]_{\mathrm{pmol}} \mathrm{L-1}=0.8\left[\mathrm{MMHg}_{\mathrm{P}}\right]_{\text {pmol L-1 }}+0.3\right)$ but negatively with $\mathrm{MMHg}_{\mathrm{D}}\left(\mathrm{r}^{2}=0.55\right.$; $\left.\left[\mathrm{MMHg}_{\mathrm{UnF}}\right]_{\mathrm{pmol}} \mathrm{L}-1=-3.7\left[\mathrm{MMHg}_{\mathrm{D}}\right]_{\mathrm{pmol}} \mathrm{L}-1+1.7\right)$. The surface water loading with authigenic MMHg was supported by paired distributions of $\mathrm{MMHg}_{\mathrm{P}}$ and particulate organic carbon $\left(\mathrm{r}^{2}=0.46 ;[\mathrm{MMHg}]_{\mathrm{pmol}} \mathrm{L-1}=\right.$ $\left.5[\mathrm{POC}]_{\mathrm{mmol}} \mathrm{L}-1+0.7\right)$. Finally, as for HgT species, high MMHgunF concentrations were measured at the AWI of the ancient Sinnamary riverbed stations (up to $3.8 \mathrm{pmol} \mathrm{L}^{-1}$ ). 
Since volatile dimethylmercury $\left(\mathrm{H}_{3} \mathrm{C}-\mathrm{Hg}-\mathrm{CH}_{3}\right)$ dissociates to MMHg in acidic waters, DGM was mostly present as $\mathrm{Hg}^{0}$. According to Amouroux et al. (1999), about $99 \%$ of DGM consisted of $\mathrm{Hg}^{0}$. Considering our data (the 2003/04 period), DGM in surface waters averaged $350 \pm 200 \mathrm{fmol} \mathrm{L}^{-1}(\mathrm{n}=$ 70), which was twice the 1999 measured concentrations (close to $190 \mathrm{fmol} \mathrm{L}^{-1}$ ). In the dry season, DGM at the AWI constituted $10 \pm 7 \%$ of $\mathrm{HgT}_{\mathrm{D}}$ and reached up to $25 \%$ at the ancient Sinnamary riverbed stations (Table 2). The high insolation (occasionally above $1 \mathrm{kWh} \mathrm{m}^{-2}$ ) coupled to the reduced cloud / vegetation cover depicted the ancient Sinnamary riverbed as a privileged site for DGM production. Indeed, DGM rose from $230 \pm 130$ to $480 \pm 270 \mathrm{fmol} \mathrm{L}^{-1}$ between wet and dry seasons and from $100 \pm 20$ to $480 \pm 150 \mathrm{fmol} \mathrm{L}^{-1}$ between the remote flooded forest and the ancient Sinnamary riverbed.

\subsubsection{In vitro $\mathrm{Hg}$ monitoring}

The Hg speciation has been examined for (i) DGM in surface water samples regularly collected during a day long period and (ii) DGM production either in the presence of light or in dark conditions (Fig. 5).

(i) DGM concentrations at the AWI were monitored with a 2 hour time lapse (Fig. 5). Concentrations exhibited a steady increase of $60 \mathrm{fmol} \mathrm{L}^{-1} \mathrm{~h}^{-1}$ that started early in the morning and lasted until late afternoon $\left(640 \mathrm{fmol} \mathrm{L}^{-1}\right)$. As dark conditions prevailed, DGM at the AWI declined $\left(35 \mathrm{fmol} \mathrm{L}^{-1} \mathrm{~h}^{-1}\right)$ and reached its lowest concentration prior to sunrise $\left(70 \mathrm{fmol} \mathrm{L}^{-1}\right)$. This pattern, observed during the dry season, would be extensively altered by changes in atmospheric conditions. Indeed, the cloudy weather and the homogenized epilimnion that depicted the short wet season ensured low DGM concentrations and poor diurnal variability $\left(180 \pm 45 \mathrm{fmol} \mathrm{L}^{-1}\right)$.

(ii) DGM was monitored in 50-100 $\mathrm{mL}$ of surface water samples taken from two simultaneously collected $2 \mathrm{~L}$ stock solutions. One was exposed to the direct sunlight whereas the other was kept in dark conditions (Fig. 5). Both solutions were gently agitated (50 RPM). The temperature was stable (around $29^{\circ} \mathrm{C}$ ). Light exposed samples displayed 3 times higher DGM concentrations than unexposed ones $\left(670 \pm 100\right.$ vs $\left.220 \pm 150 \mathrm{fmol} \mathrm{L}^{-1}\right)$. Despite the marked shift in concentrations, dark and light exposed water samples exhibited analogous patterns: sequential phases of DGM production and consumption. The overall production / consumption kinetics were 430 and $410 \mathrm{fmol} \mathrm{L}^{-1} \mathrm{~h}^{-1}$, respectively.

\section{Discussion}

\subsection{Mercury in the atmosphere}

The proximity to the Atlantic Ocean supposes three distinct sources of atmospheric $\mathrm{Hg}$ : (i) the marine aerosols enriched in $\mathrm{Na}^{+}, \mathrm{Mg}^{2+}$ and $\mathrm{SO}_{4}^{2-}$, (ii) the transatlantic terrigenous source due to the transport on a large scale of African aerosols partially enriched in $\mathrm{Ca}^{2+}$ and $\mathrm{SO}_{4}{ }^{2-}$ and (iii) the biogenic source resulting from the local vegetation. According to Meteo-France (2005), the marine source dominated in the course of 2003-2004. As a result, average TGM concentration at the dam station (12 $\left.\pm 2 \mathrm{pmol} \mathrm{m}^{-3}\right)$ was comparable to the mean North Atlantic level of $11.5 \mathrm{pmol} \mathrm{m}^{-3}$ (Slerm and Langer, 1992).

In humid tropical climates, heavy rainfall increases soil $\mathrm{Hg}$ mobility (Guedron et al., 2006). Accordingly, weathering and high average insolation $\left(>0.20 \mathrm{kWh} \mathrm{m}^{-2}\right)$ accelerates its change from the oxidised state, $\mathrm{Hg}^{\pi}$, to the reduced gaseous state, $\mathrm{Hg}^{0}$, which escapes into the atmosphere. This was supported by an increase in GEM concentrations (up to $14.5 \mathrm{pmol} \mathrm{m}^{-3}$ ) in response to the wet season heavy rainfall $\left(r^{2}=0.45\right)$. Increases in GEM emissions from irrigated soils had also been reported for the Nevada (USA) desert by Lindberg et al. (1999). The monitoring of atmospheric $\mathrm{Hg}$ exhibited a positive correlation between GEM and $\mathrm{pH}$ of rainfall $\left(\mathrm{r}^{2}=0.62\right)$. This relationship (Fig. 6) suggested that acid rains might contribute to washout GEM from the atmosphere. Since pH was positively correlated to the amount of rainfall $\left(r^{2}=0.42\right)$, the maximum GEM removal would take place in dry seasons. This period displayed highest $\mathrm{HgT}_{\mathrm{UNF}}$ concentrations in rain (up to $57.5 \mathrm{pmol} \mathrm{L}^{-1}$, November 2004). More striking was the daytime reverse correlation between GEM and RGM: the minimum of GEM, observed during the late day period, corresponded to a maximum of RGM (Fig. 2). According to various authors (Iverfeldt and Lindqvist, 1986; Mason et al., 2001; Poissant et al., 2005), the marked increase in the RGM concentrations would be the result of the photochemically induced oxidation of atmospheric $\mathrm{Hg}^{0}$. Although the majority of atmospheric $\mathrm{Hg}$ was present in elemental form, RGM has much higher wet and dry deposition rates than GEM. It thus might contribute to the deposition of $\mathrm{Hg}$ in the reservoir. 
The highest concentrations of $\mathrm{HgT}_{\mathrm{UNF}}$ in rain were measured in the late dry seasons (Table 2). A possible explanation for these elevated values would be the episodic intensification of slash and burn cultures that release $\mathrm{Hg}$ from the vegetation and the soil surfaces. According to Richard (2001), the decline of the marine ionic signature in aerosols $\left(\mathrm{Cl}^{-}, \mathrm{Na}^{+}\right.$and $\left.\mathrm{Mg}^{2+}\right)$, observed during the dry seasons, was concomitant with an increase of the fire signature (i.e. $\mathrm{K}^{+}$and $\mathrm{NO}_{3}{ }^{-}$species). Another reason accounting for the $\mathrm{HgT}_{\mathrm{UNF}}$ temporal pattern could be rain acidity. We observed that $\mathrm{pH}$ in rain presented lower values in the dry seasons ( 4.4 units) than in the wet seasons (5.0 units). Acidification of rain through increase in organic (oxalic and/or acetic) acids concentrations (Richard, 2001), would enhance GEM oxidation and promote $\mathrm{Hg}$ transfer towards the rain droplets (Fig. 6). According to Gårdfeldt and Jonsson (2003a) and Ababneh et al. (2006), chlorides and $\mathrm{HO}_{2}{ }^{\circ} \mathrm{O}_{2}{ }^{-{ }^{-}}$radicals (the oxalate photolysis products) in an aerated solution at $\mathrm{pH}$ values of $\leq 4$ cause $\mathrm{Hg}^{0}$ oxidation. Conversely, the low concentrations observed in the wet season indicate the existence of a long-term dilution process that had already been described for the Maryland (USA) seashore by Lawson and Mason (2001). Accordingly, heavy rainfall would simultaneously contribute to the partial removal of the $\mathrm{Hg}$-aerosol bounded fraction and to the dilution of $\mathrm{Hg}^{0}$ in rain. As the local atmosphere progressively becomes depleted of $\mathrm{Hg}$, concentrations in rain would drop even more.

Regarding $\mathrm{Hg}$ speciation in rain, the percentage of $\mathrm{HgR}_{\mathrm{UNF}}\left(20 \%\right.$ of $\mathrm{HgT}_{\mathrm{UNF}}$ ) was high in comparison with data from temperate latitudes or in the absence of direct oceanic influence (Mason et al., 1997). Yet, it was low compared to central oceanic regions: $72 \%$ of $\mathrm{HgT}$ in rainfalls collected above the South and Equatorial Atlantic Ocean (Lamborg et al., 1999). Hence, the HgR UNF / HgT UnF ratios confirm that the air masses around the Petit-Saut reservoir were typical of those of continental areas with a very strong marine influence. The local concentrations of MMHgunF significantly increased with rain acidity $\left(r^{2}=0.52\right)$. This suggests that detected $\mathrm{MMHg}_{\mathrm{uNF}}$ is either the result of the photochemical degradation of ambient dimethylmercury $\left(\mathrm{H}_{3} \mathrm{C}-\mathrm{Hg}-\mathrm{CH}_{3}\right)$ or the result of the abiotic methylation within the rain droplets. Since dimethylmercury evasion rates were likely to be low (Section 4.3.1.) and because maxima of $\mathrm{MMHg}_{\mathrm{uNF}}$ concentrations (up to $10 \mathrm{pmol} \mathrm{L}^{-1}$ ) occurred in the presence of organic acids (released during the annual slash and burn period), we hypothesized that $\mathrm{MMHg}$ in the rain droplets was from abiotic methylation. Such mechanisms (including the presence of organic acids) were investigated by Gårdfeldt et al. (2003b).

\subsection{Mercury exchanges at the Air-Water interface}

The annual precipitation rate for the $2003 / 04$ period averaged $3000 \mathrm{~mm}$. Multiplying this value by the measured concentrations in rain, we determined the $\mathrm{Hg}$ wet deposition to the reservoir (Table 3). The $\mathrm{HgT}_{\mathrm{UNF}}, \mathrm{HgR}_{\mathrm{UNF}}, \mathrm{DGM}$ and MMHg UNF wet depositions averaged $46 \pm 35,9 \pm 11,2 \pm 3$ and $3 \pm 5 \mathrm{nmol}$ $\mathrm{m}^{-2} \mathrm{yr}^{-1}$, respectively. Transposed to the 2003/04 flooded area $\left(\sim 230 \mathrm{~km}^{2}\right)$, the annual amounts of deposited HgT UNF, HgR UNF, DGM and MMHgunF were 11, 2, 0.5 and 0.7 moles (i.e. 2200, 400, 100 and $140 \mathrm{~g}$ ). Since the rainfall amount diluted the $\mathrm{Hg}$ concentrations, the wet deposition fluxes were balanced during the whole year. However, the dry seasons corresponded to reduced rainfalls with high $\mathrm{Hg}$ concentrations $\left(30 \pm 20 \mathrm{~mm}\right.$ week $^{-1}$ of $\left.20 \pm 14 \mathrm{pmol}^{-1} \mathrm{HgT}_{\mathrm{UNF}}\right)$ whereas the wet seasons accumulated high rainfalls with low $\mathrm{Hg}$ contents $\left(70 \pm 50 \mathrm{~mm}^{\text {week }}{ }^{-1}\right.$ of $\left.10 \pm 6 \mathrm{pmol} \mathrm{L}^{-1} \mathrm{HgT}_{\mathrm{UNF}}\right)$. Except for MMHgunf, reported values were in the low range of data found in the literature (Mason et al., 1997, 1999). Besides, the total atmospheric deposition of $\mathrm{Hg}$ has previously been estimated using ${ }^{210} \mathrm{~Pb}$ and $\mathrm{HgT}$ data in air, rain and atmosphere ("Mercure en Guyane" program, 2001). According to these authors, $\mathrm{Hg}$ deposition within the reservoir area reaches a minimum of $60 \mathrm{nmol} \mathrm{m}{ }^{-2} \mathrm{yr}^{-1}$. Analogous estimates were reported by Lacerda et al. (1999) for the whole Amazonian basin (40-60 nmol $\mathrm{m}^{-2} \mathrm{yr}^{-1}$ ). With $46 \mathrm{nmol} \mathrm{m}^{-2} \mathrm{yr}^{-1}$, wet deposition corresponded to up to $75 \%$ of total atmospheric $\mathrm{Hg}$ deposition. This result underlines the fact that rainfall represents an efficient pathway for atmospheric $\mathrm{Hg}$ to reach the Petit-Saut reservoir.

As previously shown by Peretyazhko et al. (2006), DGM peaked at the AWI of the reservoir due to photochemical reduction of dissolved $\mathrm{Hg}$ species. Both DGM and GEM at the AWI showed a broad variability with insolation that drove photochemical and photosynthetic processes (Figs. 2 and 5). Despite the fact that the maximum production rate was observed during the day period, all water samples were found supersaturated with DGM relative to the atmosphere. As the surface waters represented a potential source of $\mathrm{Hg}^{0}$ to the atmosphere, the lake-air transfer was estimated by the following relation: 


$$
\text { Flux }=\mathrm{K}\left(\mathrm{C}_{\mathrm{a}} \mathrm{H}^{-1}-\mathrm{C}_{\mathrm{w}}\right)
$$

where $C_{a}$ is the air concentration of GEM $\left(12 \pm 2 \mathrm{pmol} \mathrm{m}^{-3}\right)$ and $\mathrm{C}_{\mathrm{w}}$ the water concentration of DGM $\left(350 \pm 200 \mathrm{fmol} \mathrm{L}^{-1}\right)$. Long-term stability of temperature and wind speed ensured good precision of the various model parameters (Section 3). The mass transfer coefficient of $\mathrm{Hg}^{0}\left(\mathrm{~K}=3.4 \pm 1.5 \mathrm{~cm} \mathrm{~h}^{-1}\right)$ was correlated with the mass transfer of $\mathrm{CO}_{2}$ across the air-water interface (Wanninkhof et al., 1985; Hornbuckle et al., 1994):

$$
K=\left(0.45 U_{10}^{1.64}\right)\left[S c_{\mathrm{w}}\left(\mathrm{Hg}^{9}\right) / S c_{\mathrm{w}}\left(\mathrm{CO}_{2}\right)\right]^{-0.5}
$$

where $U_{10}$ is the wind speed $\left(3 \pm 1 \mathrm{~m} \mathrm{~s}^{-1}\right)$ at $10 \mathrm{~m}, \mathrm{Sc}_{\mathrm{w}}\left(\mathrm{CO}_{2}\right)$ and $\mathrm{Sc}_{\mathrm{w}}\left(\mathrm{Hg}^{0}\right)$ are the Schmidt numbers for $\mathrm{Hg}^{0}$ and $\mathrm{CO}_{2}$ in water $\left(560\right.$ and 315 at $\left.28^{\circ} \mathrm{C}\right)$. The Henry coefficient $\left(\mathrm{H}=466 \mathrm{~atm} \mathrm{~mol}{ }^{-1}\right.$ at $\left.28^{\circ} \mathrm{C}\right)$ is calculated using the temperature-corrected dependency

$$
\log \mathrm{H}=-1078 / \mathrm{T}+6.25 ; \mathrm{T}
$$

$\left({ }^{\circ} \mathrm{K}\right)$.

The $\mathrm{Hg}^{0}$ effluxes averaged $400 \pm 240$ and $130 \pm 100 \mathrm{pmol} \mathrm{m}^{-2} \mathrm{~d}^{-1}$ in the dry and wet seasons. On an annual basis, the AWI degassing reached $90 \pm 50 \mathrm{nmol} \mathrm{m}^{-2} \mathrm{yr}^{-1}$ (Table 3). This was comparable to several temperate lakes from Wisconsin (Vandal et al., 1991), Ontario (Amyot et al., 1997b) or Michigan (Mason and Sullivan, 1997). Comparatively, the $\mathrm{Hg}^{0}$ efflux from the Petit-Saut reservoir was twice as large as the wet mean deposition of $\mathrm{HgT}_{\mathrm{UNF}}\left(46 \pm 35 \mathrm{nmol} \mathrm{m}^{-2} \mathrm{yr}^{-1}\right)$. Yet, this ratio displayed a broad seasonal variability as wet deposition prevailed during wet seasons (150 vs $\left.130 \mathrm{pmol} \mathrm{m}^{-2} \mathrm{~d}^{-1}\right)$ while effluxes dominated during dry seasons (400 vs $100 \mathrm{pmol} \mathrm{m}^{-2} \mathrm{~d}^{-1}$ ).

The diel variations of aquatic DGM anticorrelated with atmospheric GEM but were analogous to RGM pattern (see Sections 4.1. and 4.3.). RGM is thought to be produced through photolytic degradation of GEM (via potential reactions with $\mathrm{O}_{3}, \mathrm{H}_{2} \mathrm{O}_{2}, \mathrm{OH}^{\circ}$, etc.) and also constitutes a privileged sink for gaseous atmospheric $\mathrm{Hg}$ towards rain and/or aerosols (Lu and Schroeder, 1998; Hedgecock et al., 2003; Poissant et al., 2005). Thus, RGM production and deposition may determine the $\mathrm{Hg}$ atmospheric lifetime. The local RGM deposition was determined through the formula proposed by Laurier (pers com.):

$$
\text { Flux }=k_{A}(R G M)
$$

where $\mathrm{k}_{\mathrm{A}}$ is the air-side mass transfer coefficient $\left(1.6 \pm 0.7 \mathrm{~cm} \mathrm{~s}^{-1}\right)$ calculated using the air-side diffusion coefficient $\left(D_{A}=0.28 \mathrm{~cm}^{2} \mathrm{~s}^{-1}\right)$ and the wind speed $10 \mathrm{~m}$ above the water surface $\left(\mathrm{U}_{10}=3 \pm 1\right.$ $\mathrm{m} \mathrm{s}^{-1}$ )

$$
\mathrm{k}_{\mathrm{A}}=\mathrm{D}_{\mathrm{A}}^{0.5}\left[(0.98 \pm 0.1) \mathrm{U}_{10}+(1.26 \pm 0.3)\right]
$$

where \pm is the $95 \%$ confidence interval. The mean RGM deposition was $2.0 \pm 1.5 \mathrm{nmol} \mathrm{m}^{-2} \mathrm{yr}^{-1}$, which represented 4 and $13 \%$ of the wet and dry HgT deposition, respectively (Table 3 ). Recorded patterns of DGM, GEM and RGM concentrations (Figs. 2 and 5) suggested that atmospheric gaseous $\mathrm{Hg}$ is preferentially oxidized during the day period (maximum of RGM), contributing to the observed decrease of GEM (around $8 \mathrm{pmol} \mathrm{m}^{-3}$ ) and the increase of DGM $\left(350 \mathrm{pmol} \mathrm{m}^{-3}\right)$. Considering that GEM from the first few $10 \mathrm{~m}$ height air-column is readily transferable as RGM to the reservoir, the diel atmospheric deposition would represent close to $20 \%$ of the AWI measured DGM increase. In these particular conditions, the calculated deposition flux should average $150 \pm 100 \mathrm{pmol} \mathrm{m}^{-2} \mathrm{~d}^{-1}$, which is compatible with the total atmospheric deposition ranges but exceeds that of reactive $\mathrm{Hg}$ (160 and 5 pmol m${ }^{-2} d^{-1}$, respectively). This result underlines that either (i) RGM production and subsequent 
deposition occurs in the close vicinity ( $<1 \mathrm{~m}$ distance) of the AWI and/or (ii) that RGM production takes place during short spans (less than a few hours) of intense solar exposure.

\subsection{AWI mercury transformations and budget}

At the AWI, redox conditions and biologically mediated reactions are expected to play a major role in controlling the availability of $\mathrm{Hg}$ species for reduction / oxidation processes (Beucher et al., 2002; Lanzillotta et al., 2004; Peretyazhko et al., 2005). In order to probe these transformations, let us consider the in situ and incubation experiments presented in Section 4.3. (Fig. 5). From the in situ experiment (i) we concluded that light exposure significantly enhances the overall DGM levels (Amyot et al., 2001). According to Beucher et al. (2002), AWI maxima DGM concentrations (10\% of the HgT $)$ reflect the photochemical production of $\mathrm{Hg}^{0}$ in the presence of a reductive agent such as organic matter and especially iron-carboxylated ionic complexants. Experiment (ii) showed that direct light exposure barely accounted for the observed minute to hour scale variations (on the range of the 0.1 pmol $\mathrm{L}^{-1}$ ). Rapid $\mathrm{Hg}$ oxidation / reduction mechanisms have already been reported in the literature by Siciliano et al. (2002) and Garcia et al. (2005). Accordingly, observed variability reflected the response of (epi)neuston to the photochemical or endogenical production of oxidant species $\left(\mathrm{O}_{3}, \mathrm{H}_{2} \mathrm{O}_{2}, \mathrm{OH}^{\prime}\right.$, etc.).

As shown in Section 5.2. (and in Fig. 7), the 2003/04 annual Petit-Saut reservoir wet depositions averaged 11, 2, 0.5 and 0.7 moles (i.e. 2200, 400, 100 and 140 grams) for $\mathrm{HgT}_{\mathrm{UNF}}, \mathrm{HgR} \mathrm{UNF}_{\mathrm{NF}}$, DGM and MMHg UNF, respectively. With $46 \pm 35 \mathrm{nmol} \mathrm{m}^{-2} \mathrm{yr}^{-1}$, the $\mathrm{HgT}_{\text {UNF }}$ wet atmospheric deposition constituted nearly $75 \%$ of the total $\left(60 \mathrm{nmol} \mathrm{m}^{-2} \mathrm{yr}^{-1}\right)$. This was about half that measured by Da Silva et al. (2006) for the inland Negro River basin $\left(115 \mathrm{nmol} \mathrm{m}^{-2} \mathrm{yr}^{-1}\right)$. This observation, coupled to comparable fluxes for the South and equatorial Atlantic (18-36 nmol m $\mathrm{m}^{-2} \mathrm{yr}^{-1}$; Lamborg et al., 1999), supports the dominant oceanic contribution of rainfall $\mathrm{HgT}_{\mathrm{UNF}}$ in the vicinity of the reservoir (Table 4). Considering the emissions, despite the uncertainty surrounding figures, there is a strong suggestion that the reservoir represented a source of $\mathrm{Hg}^{0}$ to the atmosphere. $\mathrm{Hg}^{0}$ volatilization at the AWI was estimated as $90 \pm 50 \mathrm{nmol} \mathrm{m}^{-2} \mathrm{yr}^{-1}$. This was higher than the average value for the Negro River flooded area (around $20 \mathrm{nmol} \mathrm{m}^{-2} \mathrm{yr}^{-1}$; Da Silva et al., 2006), but comparable to the data for the Atlantic Ocean (around $110 \mathrm{nmol} \mathrm{m}^{-2} \mathrm{yr}^{-1}$; Mason et al., 2001; Gårdfeldt et al., 2003c) (Table 4). This result, presumably due to the sparse vegetation cover, typical in permanently flooded areas, underscores the role of tropical reservoirs as local but significant and durable sources of atmospheric $\mathrm{Hg}$. The 2003/04 Petit-Saut reservoir AWI depositions and emissions of $\mathrm{Hg}$ averaged 60 and $90 \mathrm{nmol} \mathrm{m}^{-2} \mathrm{yr}^{-1}$ (i.e. 2800 and $\left.4200 \mathrm{~g} \mathrm{yr}^{-1}\right)$, respectively. The reservoir / atmosphere mass balance is thrown all the more out of equilibrium when considering the waters expelled from the dam: DGM exportations then reach $4600 \mathrm{~g}$ $\mathrm{yr}^{-1}$ to which one may add the subsequent Sinnamary Estuary degassing. Indeed, from the tailrace monitoring data (Muresan et al., in press), average DGM concentrations in dam discharged waters and the annual exported amount were of the order of $300 \pm 200 \mathrm{fmol} \mathrm{L}^{-1}$ and $2 \pm 1$ moles (i.e. $400 \pm$ 200 grams).

\section{Concluding remarks}

The present study reinforces the hypothesis that artificial reservoirs in tropical regions constitute important sources for atmospheric $\mathrm{Hg}$. The application of transport-reaction models to $\mathrm{Hg}$ distributions from the Petit-Saut reservoir made it possible to monitor the atmospheric sources, determine the periods of production and consumption of DGM, GEM and RGM, and probe the reactions that regulate AWI $\mathrm{Hg}$ exchanges. They revealed (Fig. 7) that atmospheric $\mathrm{Hg}$ inputs to the reservoir represented 14 moles $\mathrm{yr}^{-1}\left(60 \mathrm{nmol} \mathrm{m}^{-2} \mathrm{yr}^{-1}\right)$ of which 75 and $3 \%$ corresponded to wet and RGM-mediated deposition (i.e. 46 and $\left.2 \mathrm{nmol} \mathrm{m}^{-2} \mathrm{yr}^{-1}\right)$, respectively. The associated DGM evasion represented 23 moles $\mathrm{yr}^{-1}$ of which 90 and $10 \%$ corresponded to AWI degassing $\left(90 \mathrm{nmol} \mathrm{m}^{-2} \mathrm{yr}^{-1}\right)$ and dam discharged amount $\left(180 \mathrm{~m}^{3} \mathrm{~s}^{-1}\right.$ at $\left.300 \pm 200 \mathrm{fmol} \mathrm{L}^{-1}\right)$. DGM, GEM and RGM displayed marked patterns of day-night cycles including oxidation, deposition, reduction and re-emission processes. These features followed the general pattern of diurnal solar radiation variations: the DGM and RGM levels were found to increase with solar radiation $\left(660\right.$ and $\left.0.05 \mathrm{fmol} \mathrm{Wh}^{-1} \mathrm{~m}^{-1}\right)$ whereas GEM concentrations declined $(-9 \mathrm{fmol} \mathrm{Wh}$ $\mathrm{m}^{-1}$ ). In surface waters, short period (minute to hour time scale) transformations ought also to be carefully considered. Biologically catalyzed reduction / oxidation mechanisms seemed to play a significant role in controlling reducible $\mathrm{Hg}$ speciation and therefore $\mathrm{Hg}^{\circ}$ volatilization. The study of such aphotic mechanisms should be useful to constrain the estimated values required in rapid and/or dark condition evasion models. 
Air and rain $\mathrm{Hg}$ levels, as determined from the Petit-Saut monitoring enabled us to differentiate between oceanic, terrigenic and anthropic sources. With the notable exception of MMHgunF (affected by the slash and burn human activity), $\mathrm{HgT}_{\mathrm{UNF}}$ in rain $\left(16 \pm 12 \mathrm{pmol} \mathrm{L}^{-1}\right)$ mostly originated from the adjacent Atlantic ocean. The average GEM concentrations at the dam station were also comparable to the mean North Atlantic level $\left(12 \pm 2\right.$ and $\left.11.5 \mathrm{pmol} \mathrm{m}^{-3}\right)$. To monitor changes in atmospheric $\mathrm{Hg}$ partition, future works may use stability constants for calculating $\mathrm{Hg}^{\prime \prime}$ speciation in rain and aerosols with respect to photochemical processes and volatile organic acids (e.g. oxalic and acetic ligands).

\section{Acknowledgments}

We would like to thank $\mathrm{C}$. Reynouard and $\mathrm{V}$. Horeau for their help in obtaining the air and rain samples. We also acknowledge F. Schaedlich from Tekran Inc. for his technical assistance. This work was supported by the French National Scientific Research Center (CNRS/PEVS, "Mercury in French Guiana" research program), the European Union Feder funds and the French Ministry for the Environment (MEDD). This work also received the financial support of Electricité de France (EDF) through a scholarship grant to one of us (BM) (\#F01381/0). Thanks are due to W. Delor and J. Harris who edited the transcript. 


\section{References}

Ababneh FA, Scott SL, Al-Reasi HA, Lean DRS. Photochemical reduction and reoxidation of aqueous mercuric chloride in the presence of ferrioxalate and air. Sci. Total Environ. 2006; 367: 831-839.

Amouroux D, Wasserman JC, Tessier E, Donard OFX. Elemental mercury in the atmosphere of a tropical Amazonian Forest (French Guiana). Environ. Sci. Technol. 1999; 33: 3044-3048.

Amyot M, Auclair JC, Poissant L. In situ high temporal resolution analysis of elemental mercury in natural waters. Anal. Chim. Acta 2001; 447: 153-159.

Amyot M, Mierle G, Lean D, McQueen DJ. Effect of solar radiation on the formation of dissolved gaseous mercury in temperate lakes. Geochim. Cosmochim. Acta 1997b; 61: 975-987.

Beucher C, Wong WCP, Richard C, Mailhot G, Bolte M, Cossa D. Dissolved gaseous mercury formation under UV irradiation of unamended tropical waters from French Guyana. Sci. Total Environ. 2002; 290: 131-138.

Bloom NS. Determination of picogram levels of methylmercury by aqueous phase ethylation followed by cryogenic gas chromatography with cold vapour atomic fluorescence detection. Can. J. Fish. Aqua. Sci. 1989; 46: 1131-1140.

Bloom NS, Watras CJ. Observations of methylmercury in precipitation. Sci. Total Environ. 1989; 8788: 199-207.

Bloom NS, Fitzgerald WF. Determination of volatile mercury species at picogram level by low temperature gas chromatography with cold-vapour atomic fluorescence detection. Anal. Chim. Acta 1988; 28: 151-161.

Cossa D, Averty B, Bretaudeau J, Sénard AS. Spéciation du mercure dissous dans les eaux marines. Méthodes d'analyse en milieu marin. Editions Ifremer, ISBN 2-84433-125-4, 2003, 27 pp.

Cossa D, Coquery M, Nakhlé K, Claisse D. Dosage du mercure total et du monomethylmercure dans les organismes et les sédiments marins. Méthodes d'analyse en milieu marin. Editions Ifremer, ISBN 2-84433-105-X, 2002, 27pp.

Da Silva GS, Jardim WF, Fadini PS. Elemental gaseous mercury flux at the water/air interface over the Negro River basin, Amazon, Brazil. Sci. Total Environ. 2006; 368: 189-198.

Da Silva GS. A dinâmica biogeoquímica do mercúrio na bacia do Negro River (AM) e fluxos na interface água/atmosfera. Doctoral Thesis, Chemistry Institute-State University of Campinas, 2004, $328 \mathrm{pp}$.

Dumestre JF, Vaquer A, Gosse P, Richard S, Labroue L. Bacterial ecology of a young equatorial hydroelectric reservoir (Petit-Saut, French Guyana). Hydrobiol. 1999; 400: 75-83.

Fadini PS, Jardim WF. Is the Negro River Basin (Amazon) impacted by naturally occurring mercury? Sci. Total Environ. 2000a; 275: 71-82.

Fitzgerald WF, Mason RP, Vandal GM. Atmospheric cycling and air-water exchange of mercury over mid-continental lacustrine regions. Water Air Soil Pollut. 1991; 56: 745-768.

Fostier H, Forti MC, Guimarães JRD, Melfi AJ, Boulet R, Espirito Santo CM, Krug FJ. Mercury fluxes in a natural forested Amazonian catchment (Serra do Navio, Amapá State, Brazil). Sci. Total Environ. 2000; 260: 201-211.

Garcia E, Poulain AJ, Amyot M, Ariya PA. Diel variations in photoinduced oxidation of $\mathrm{Hg}^{0}$ in freshwater. Chemosphere 2005; 59: 977-981.

Gårdfeldt $\mathrm{K}$, Jonsson M. Is bimolecular reduction of $\mathrm{Hg}$ (II) complexes possible in aqueous systems of environmental importance. J. Phys. Chem. 2003a; 107, 4478-4482.

Gårdfeldt K, Munthe J, Stromberg D, Lindqvist O. A kinetic study on the abiotic methylation of divalent mercury in the aqueous phase. Sci. Total Environ. 2003b; 304: 127-136.

Gårdfeldt K, Sommar J, Ferrara R, Ceccarini C, Lanzillotta E, Munthe J, Wängberg I, Lindqvist O, Pirrone N, Sprovieri F, Pesenti E, Strömberg D. Evasion of mercury from coastal and open waters of the Atlantic Ocean and the Mediterranean Sea. Atmos. Environ. 2003c; 37: 73-84.

Guedron S, Grimaldi C, Chauvel C, Spadini L, Grimaldi M. Weathering versus atmospheric contributions to mercury concentrations in French Guiana soils. App. Geochem. 2006; 21: 2010-2022.

Hall BD, Manolopoulos H, Hurley JP, Schauer JJ, St. Louis VL, Kenski D, Graydon J, Babiarz CL, Cleckner LB, Keeler GJ. Methyl and total mercury in precipitation in the Great Lakes region. Atmos. Environ. 2005; 39: 7557-7569.

Hedgecock IM, Pirrone N, Sprovieri F, Pesanti E. Reactive gaseous mercury in the marine boubdary layer. Modelling and Experimental evidence of its formation in the Mediterranean region. Atmos. Environ. 2003; 37: 21-39.

Hedgecock IM, Pirrone N. Mercury and photochemistry in the marine boundary layer-modelling studies suggest the in situ production of reactive gas phase mercury. Atmos. Environ. 2001; 35: 3055-3062. 
Hornbuckle KC, Jeremiason JD, Sweet CW, Eisenreich SJ. Seasonal variations in air-water exchange of polychlorinated biphenyls in Lake superior. Environ. Sci. Technol. 1994; 28: 1491-1501.

Huynh F, Charron C, Betoulle JL, Panechou K, Gardel A, Prost MT, Loubry D. Suivi de l'évolution géomorphologique et botanique de l'estuaire du Sinnamary par télédétection. Final report ORSTOMEDF, 1997, 64pp.

Iverfeldt $A$, Lindqvist $\mathrm{O}$. Atmospheric oxidation of elemental mercury by ozone in the aqueous phase. Atmos. Environ. 1986; 20: 1567-1573.

Lacerda LD, Ribeirto MG, Cordeiro RC, Sofeddine A, Turcq B. Atmospheric mercury deposition over Brazil during the past 30,000 years. Ciência e Cultura 1999; 51: 363-371.

Lamborg CH, Rolfhus KR, Fitzgerald WF, Kim G. The atmospheric cycling and air-sea exchange of mercury species in the South and equatorial Atlantic Ocean. Deep Sea Res. 1999; 46: 957-977.

Lanzillotta E, Ceccarini C, Ferrara R, Dini F, Frontini FP, Banchetti R. Importance of the biogenic organic matter in photo-formation of dissolved gaseous mercury in a culture of the marine diatom Chaetoceros sp. Sci. Total Environ. 2004; 318: 211-221.

Laurier FJG, Mason RP, Whalin L, Kato S. Reactive gaseous mercury formation in the North Pacific Ocean's marine boundary layer: A potential role of halogen chemistry. J. Geophys. Res. 2003; 108: art. No. 4529.

Lawson NM, Mason RP. Concentration of Mercury, Methylmercury, Cadmium, Lead, Arsenic, and Selenium in the Rain and Stream Water of Two Contrasting Watersheds in Western Maryland. Water Res. 2001; 35: 4039-4052.

Leermarkers M, Galetti S, De Galan S, Brion N, Baeyens W. Mercury in the Souther North Sea and Sheldt Estuary. Mar. Chem. 2001; 75: 229-248.

Liang L, Horvat M, Bloom NS. An improved speciation method for mercury by GC/CVAFS after aqueous phase ethylation and room temperature precollection. Talanta 1994; 41: 371-379.

Lindberg SE, Zhang H, Gustin M, Vette A, Marsik F, Owens J, Casimir A, Ebinghaus R, Fitzgerald C, Kemp J, Kock HH, London J, Majewski M, Poissant L. Increases in mercury emissions from desert soils in response to rainfall and irrigation. J. Geophys. Res. 1999; 104: 21879-21888.

Lindberg SE, Stratton WJ. Atmospheric mercury speciation: Concentrations and behavior of reactive gaseous mercury in ambient air. Environ. Sci. Technol. 1998; 32: 49-57.

Lu JY, Schroeder WH. Comparison of conventional filtration and a denuder-based methodology for sampling of particulate-phase mercury in ambient air. Talanta 1998; 49: 15-24.

Mason RP, Lawson NM, Sheu GR. Mercury in the Atlantic Ocean: factors controlling air-sea exchange of mercury and its distribution in the upper waters. Deep Sea Res. 2001; 48: 2829-2853.

Mason RP, Sheu GR. An examination of the methods for the measurements of reactive gaseous mercury in the atmosphere. Environ. Sci. Technol. 2001; 35: 1209-1216.

Mason RP, Lawson NM, Lawrence AL, Joy JL, Lee JG, Sheu GR. Mercury in the Chesapeake Bay. Mar. Chem. 1999; 65: 77-96.

Mason RP, Lawson NM, Sullivan KA. The concentration, speciation and sources of mercury in Chesapeake Bay precipitation. Atmos. Environ. 1997; 31: 3541-3550.

Mason RP, Sullivan KA. Mercury in Lake Michigan. Environ. Sci. Technol. 1997; 31: 942-947.

Mason RP, Fitzgerald WF, Morel FMM. The biogeochemical cycling of elemental mercury: anthropogenic influences. Geochim. Cosmochim. Acta 1994a; 58: 3191-3198.

"Mercure en Guyane" program. Charlet L, Boudou A, Grimaldi M, Cossa D. Region de Saint Elie et retenue de Petit-Saut. Final report part 1, 2001, 70pp.

Meteo-France: French institute for weather forecast and meteorological research. 2005 database on wind direction and rain events. http://www. meteofrance.com.

Muresan B, Cossa D, Richard S, Dominque Y. Mercury Cycling in a Tropical Artificial Reservoir: Monomethylmercury Production and Sources. Appl. Geochem., in press.

Parker JL, Bloom NS. Preservation and storage techniques for low-level aqueous mercury speciation. Sci. Total Environ. 2005; 337: 253-63.

Peretyazhko T, Van Capellen P, Meile C, Coquery M, Musso M, Regnier P, Charlet L. Biogeochemistry of major redox elements and mercury in a tropical reservoir lake (Petit-Saut, French Guiana). Aquat. Geochem. 2005; 11: 33-35.

Peretyazhko T, Charlet L, Muresan B, Kazimirov V, Cossa D. Formation of dissolved gaseous mercury in a tropical lake (Petit-Saut reservoir, French Guiana). Sci. Total Environ. 2006; 364: 260-271.

Poissant L, Pilote $\mathrm{M}$, Beauvais $\mathrm{C}$, Constant $\mathrm{P}$, Zhang HH. A year of continuous measurements of three atmospheric mercury species (GEM, RGM and Hgp) in southern Québec, Canada. Atmos. Environ. 2005; 39: 1275-1287.

Richard S. Monitoring of the IDAF (Igac / Debits / AFrique) network stations of Petit-Saut in French Guiana: the sources of emissions. IDAF/SEARCH workshop 3-5 December 2001, Toulouse, France. 
Richard S. La mise en eau du barrage de Petit-Saut. Hydrochimie 1 - du fleuve Sinnamary avant la mise en eau, 2 - de le retenue pendant la mise en eau, 3 - du fleuve en aval. Doctoral Thesis, Aix Marseille University I, 1996, 278 pp.

Schroeder WH, Anlauf KG, Barrie LA, Lu JY, Steffen A, Schneeberger DR, Berg T. Artic springtime depletion of mercury. Nature 1998; 394: 331-333.

Siciliano SD, O'Driscoll NJ, Lean DRS. Microbial reduction and oxidation of mercury in freshwater lakes. Environ. Sci. Technol. 2002; 36: 3064-3068.

Slerm F, Langer E. Increase in global atmospheric concentrations of mercury inferred from measurements over the Atlantic Ocean. Nature 1992; 355: 434-436.

Tekran Inc. (2001) Model 1130 mercury speciation unit maintenance manual. Tekran.com.

Vandal GM, Mason RP, Fitzgerald F. Cycling of volatile mercury in temperate lakes. Water Air Soil Pollut. 1991; 56: 791-803.

Veiga MM, Hinton J, Lilly C. Mercury in the Amazon: A Comprehensive Review with Special Emphasis on Bioaccumulation and Bioindicators. NIMD (National Institute for Minamata Disease) Forum'99, 1999; 19-39.

Wanninkhof R, Ledwell R, Broecker WS. Gas exchange - wind speed relationship measured with sulfur hexafluoride on a lake. Science 1985; 227: 1224-1226. 
TABLE CAPTIONS

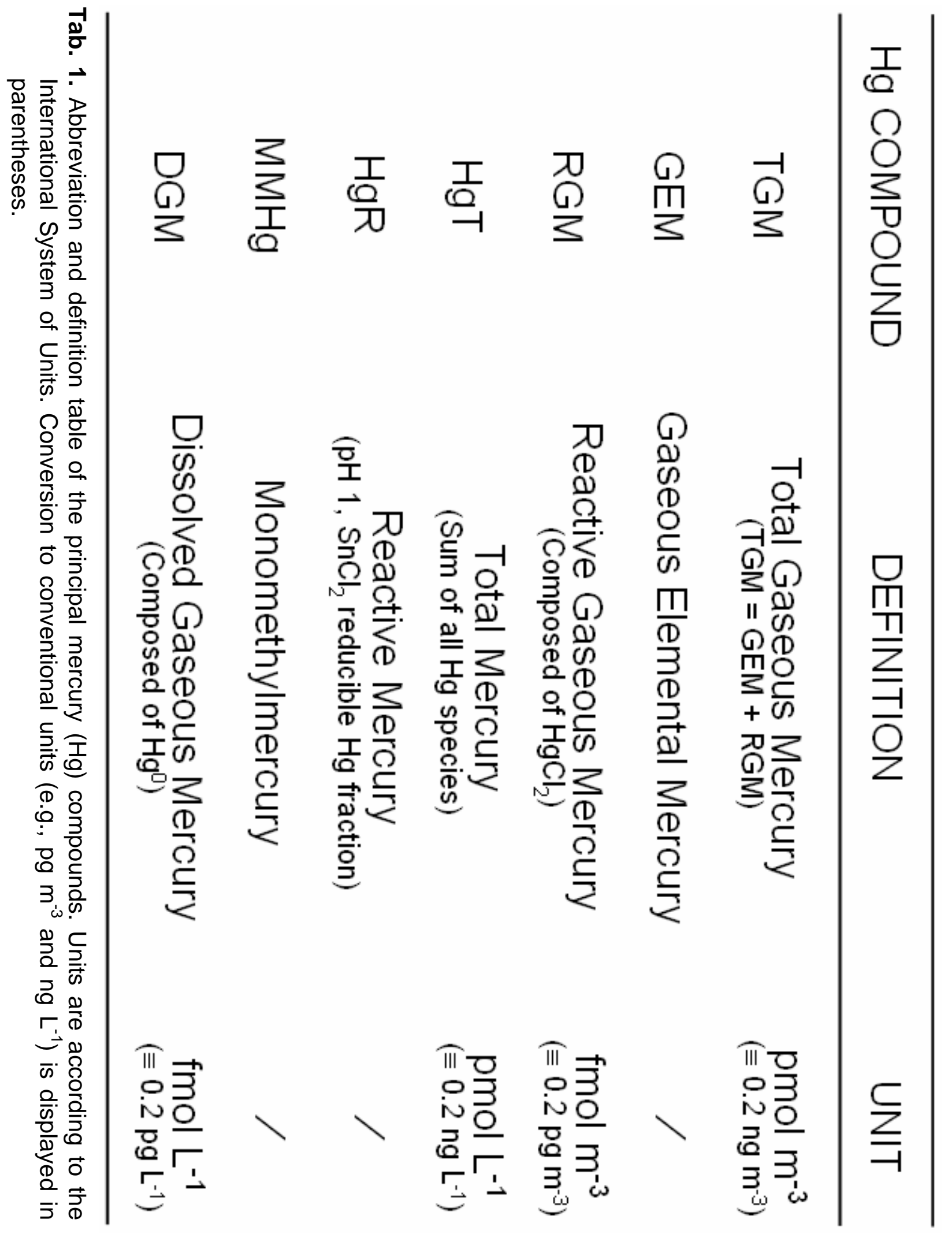




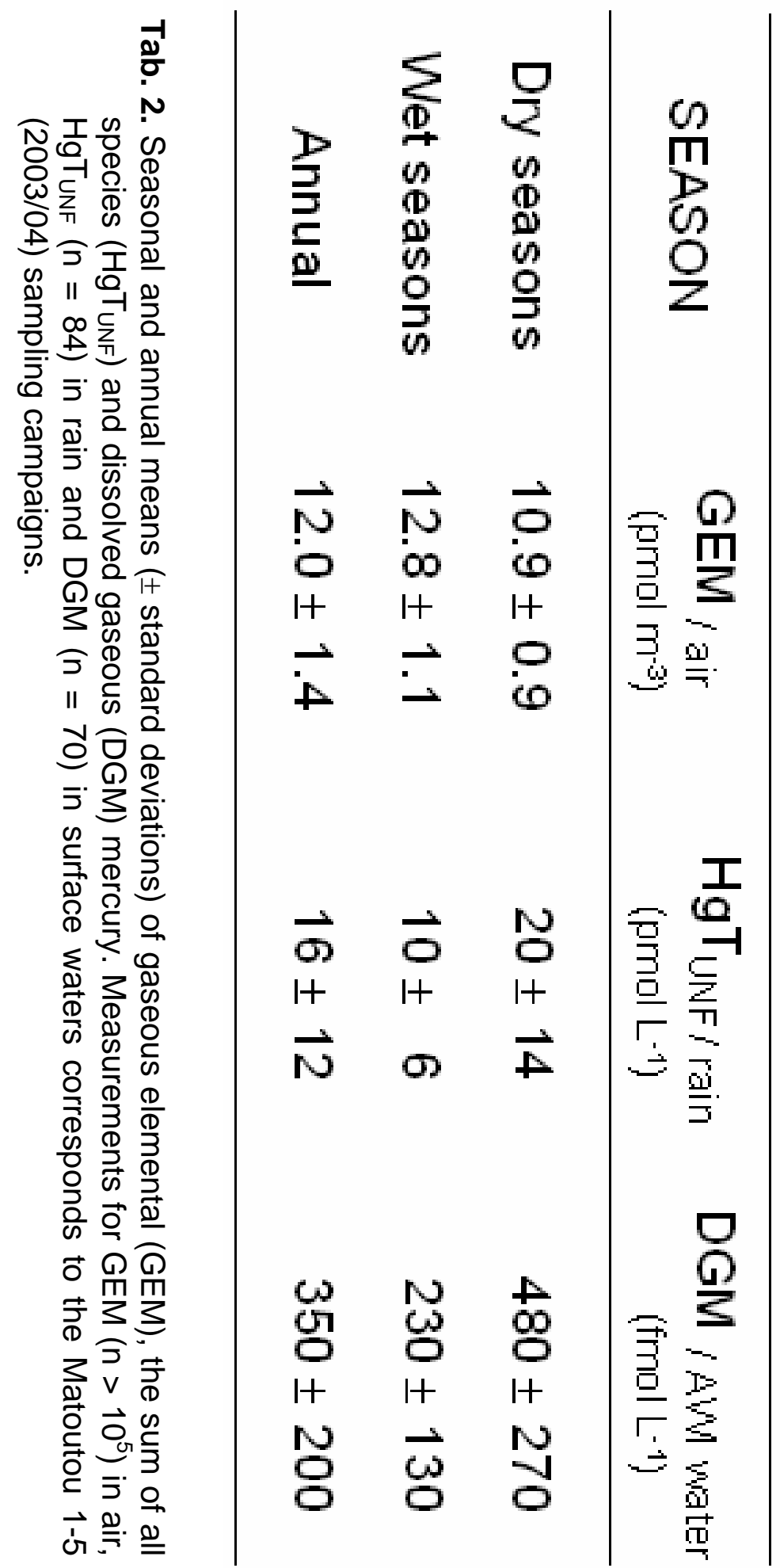




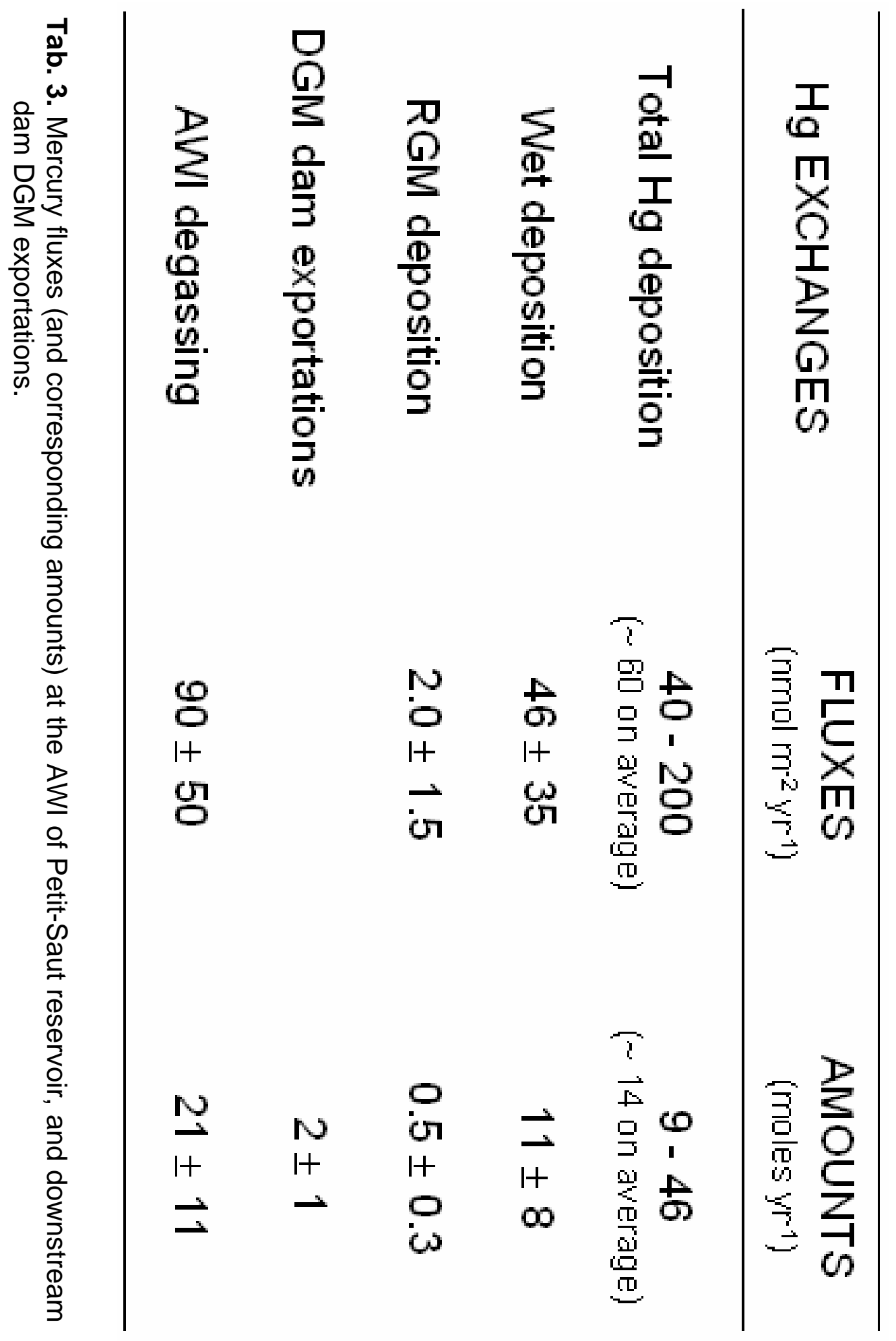




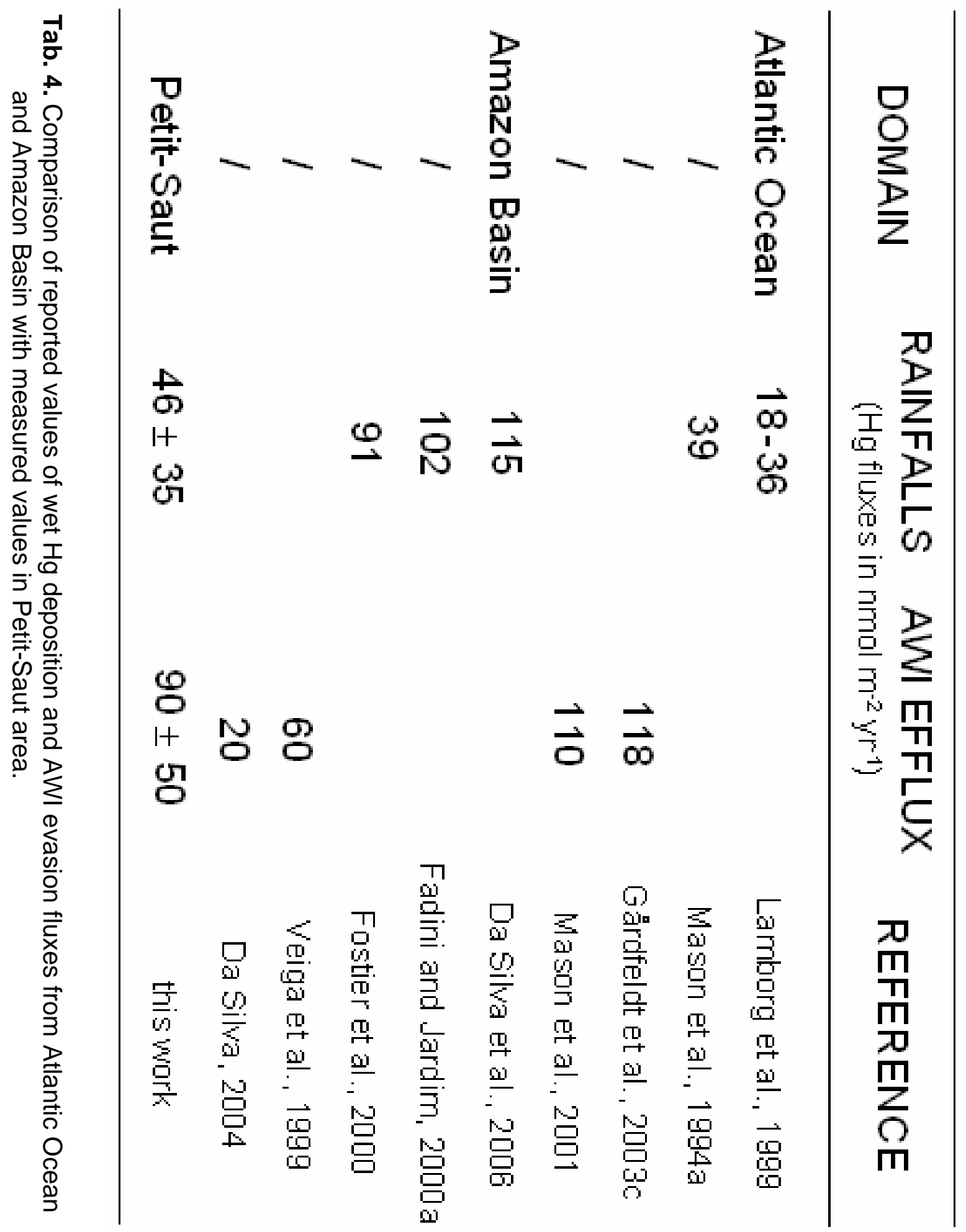




\section{FIGURE CAPTIONS}

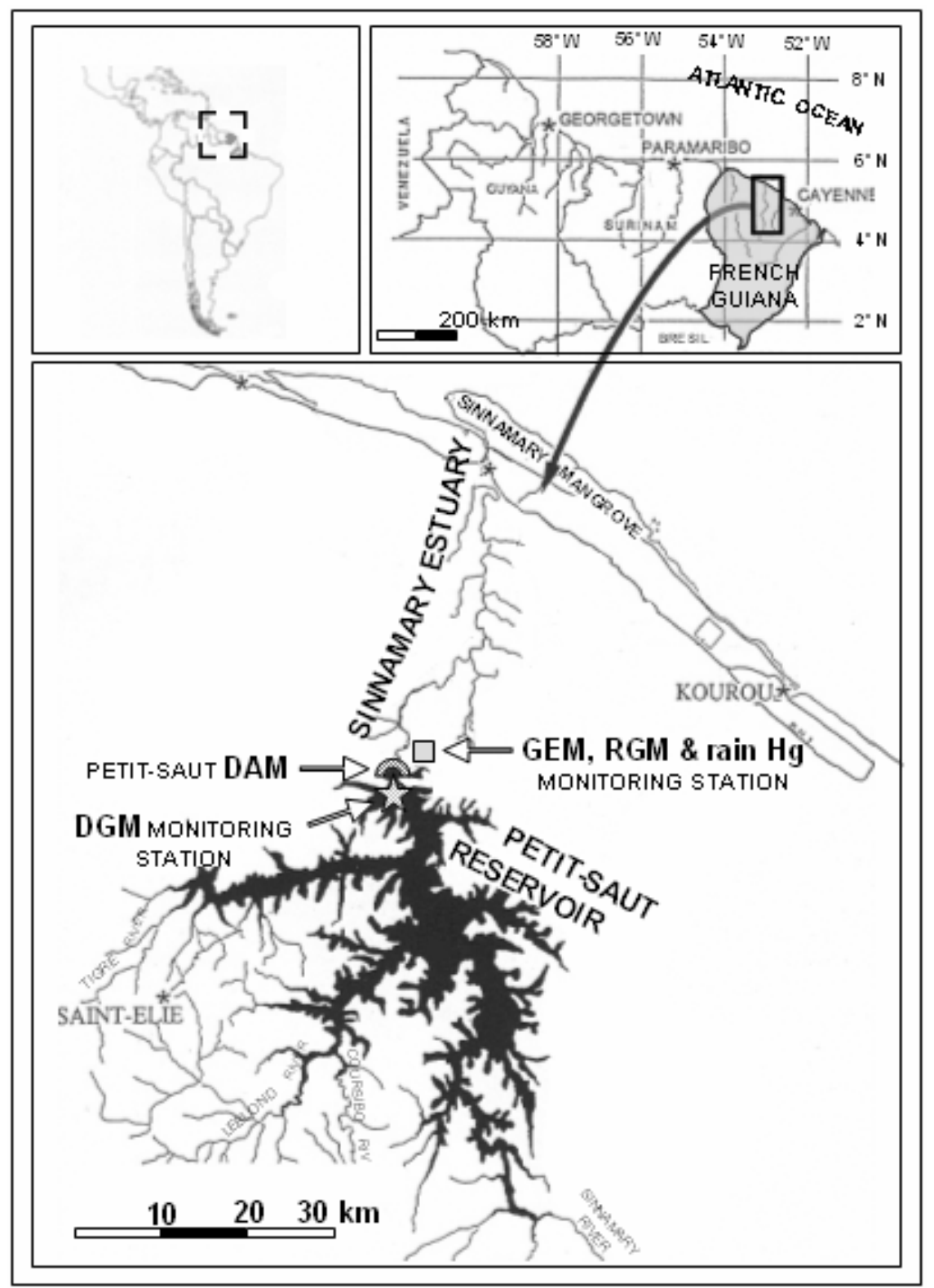

Fig. 1. Location map of the Petit-Saut reservoir / Sinnamary Estuary continuum. Detailed map of the areas where (and dates when) water sampling occurred, including associated geochemical descriptions, is given in Muresan et al. (in press). 


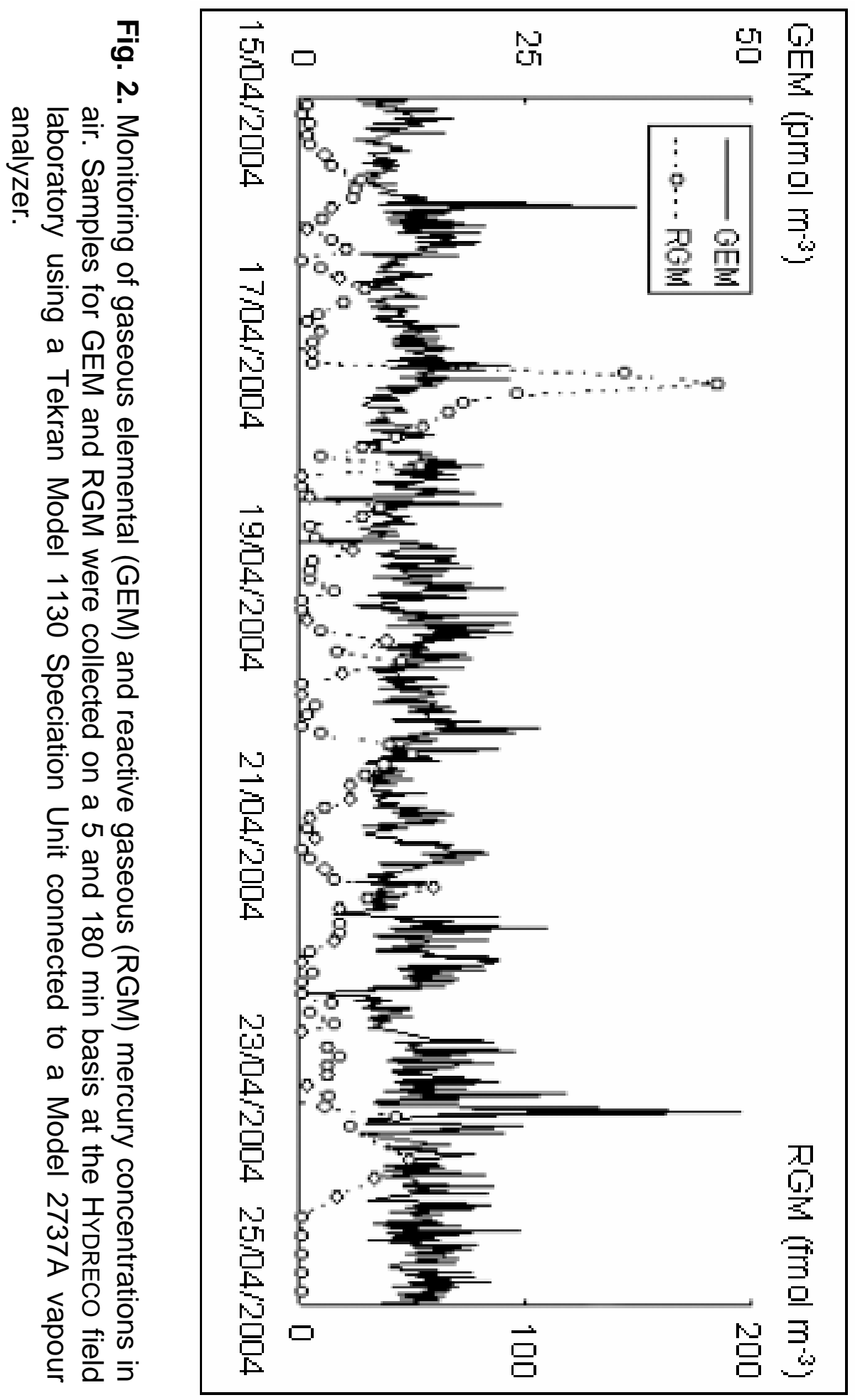




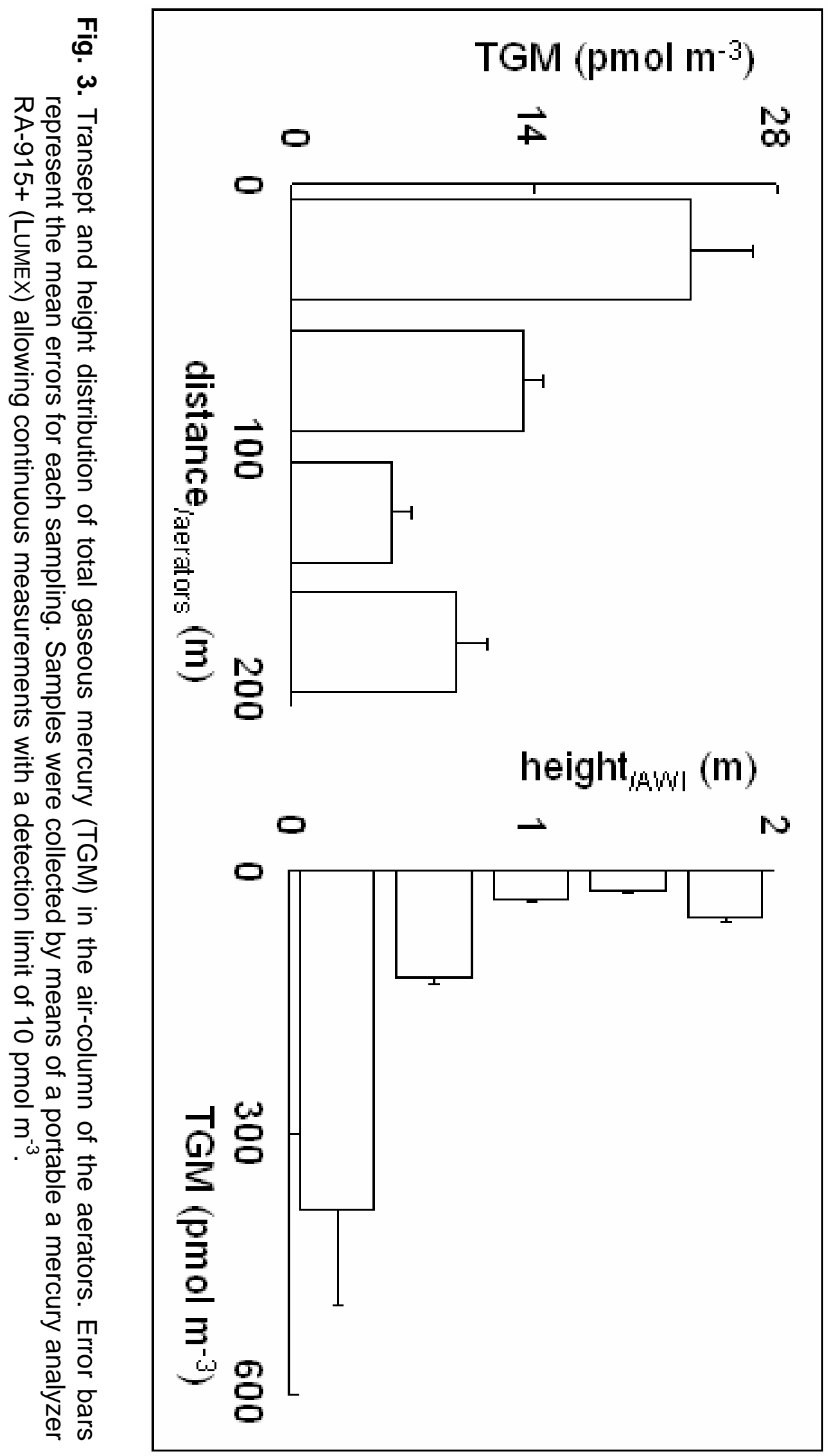




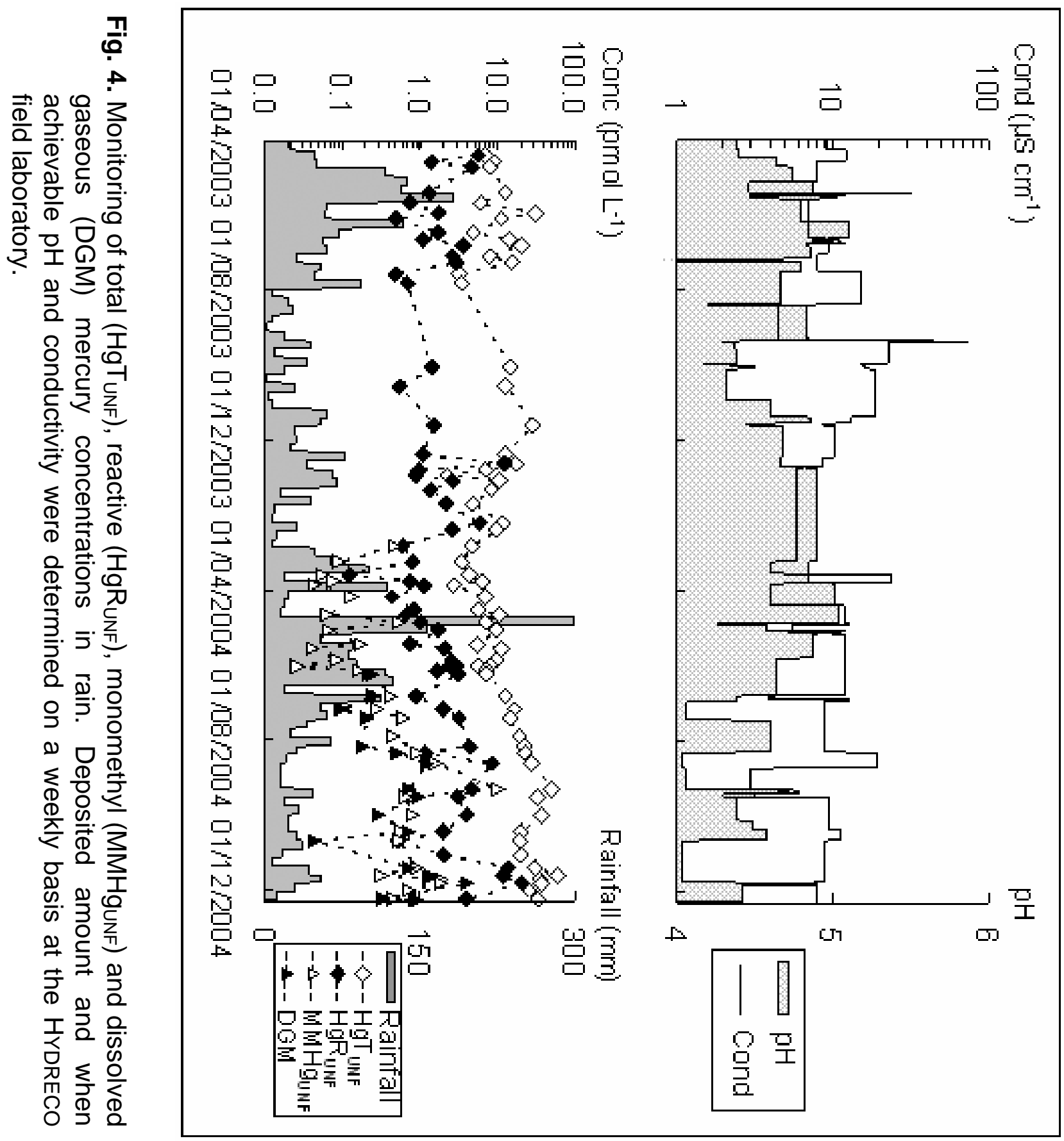




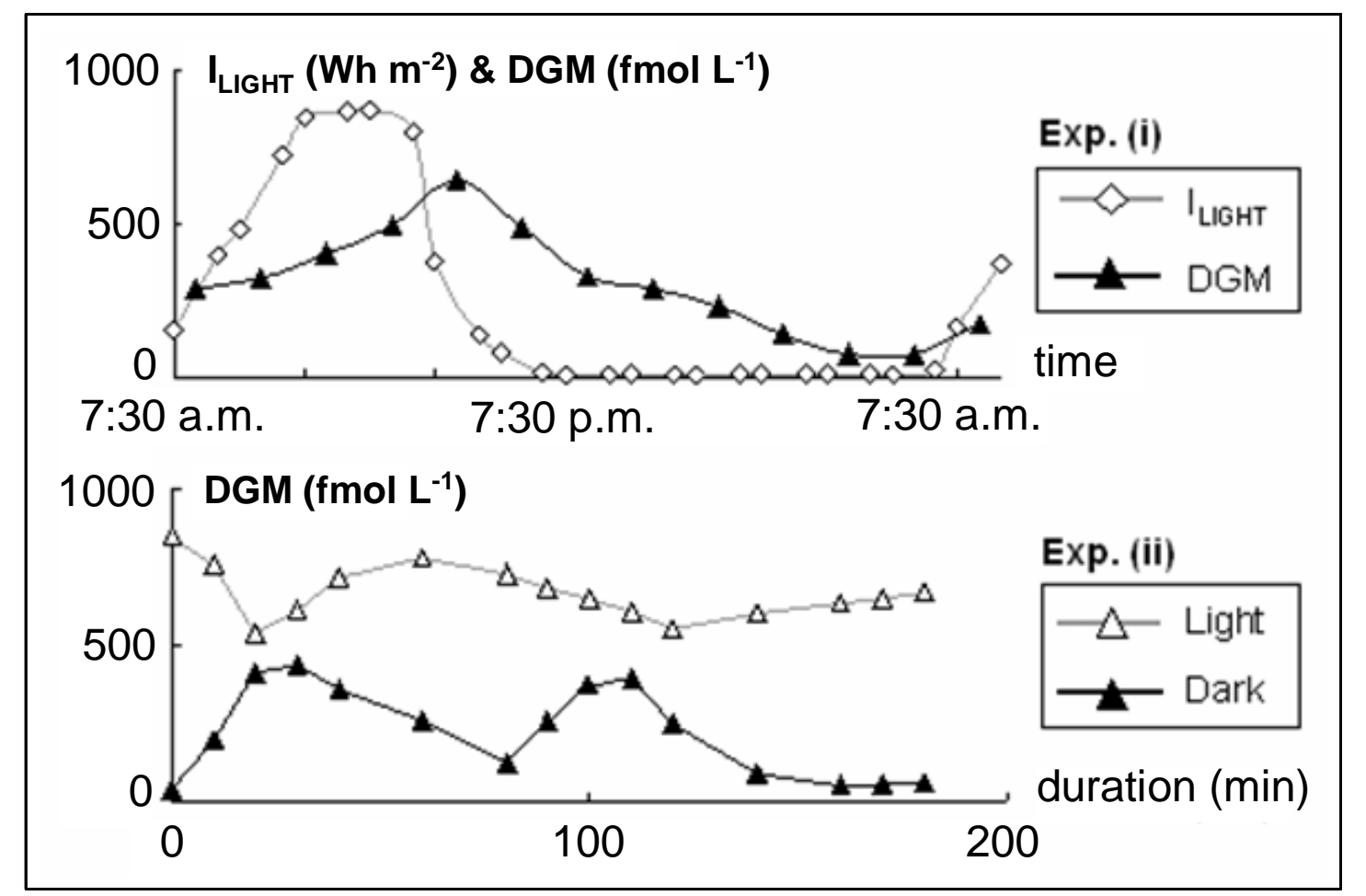

Fig. 5. Exp (i): Diel variations in the intensity of light exposure and dissolved elemental mercury (DGM) concentrations in the Petit-Saut reservoir surface waters. Exp (ii): DGM variations in surface water samples incubated in the dark or under the full spectrum of solar radiation. 


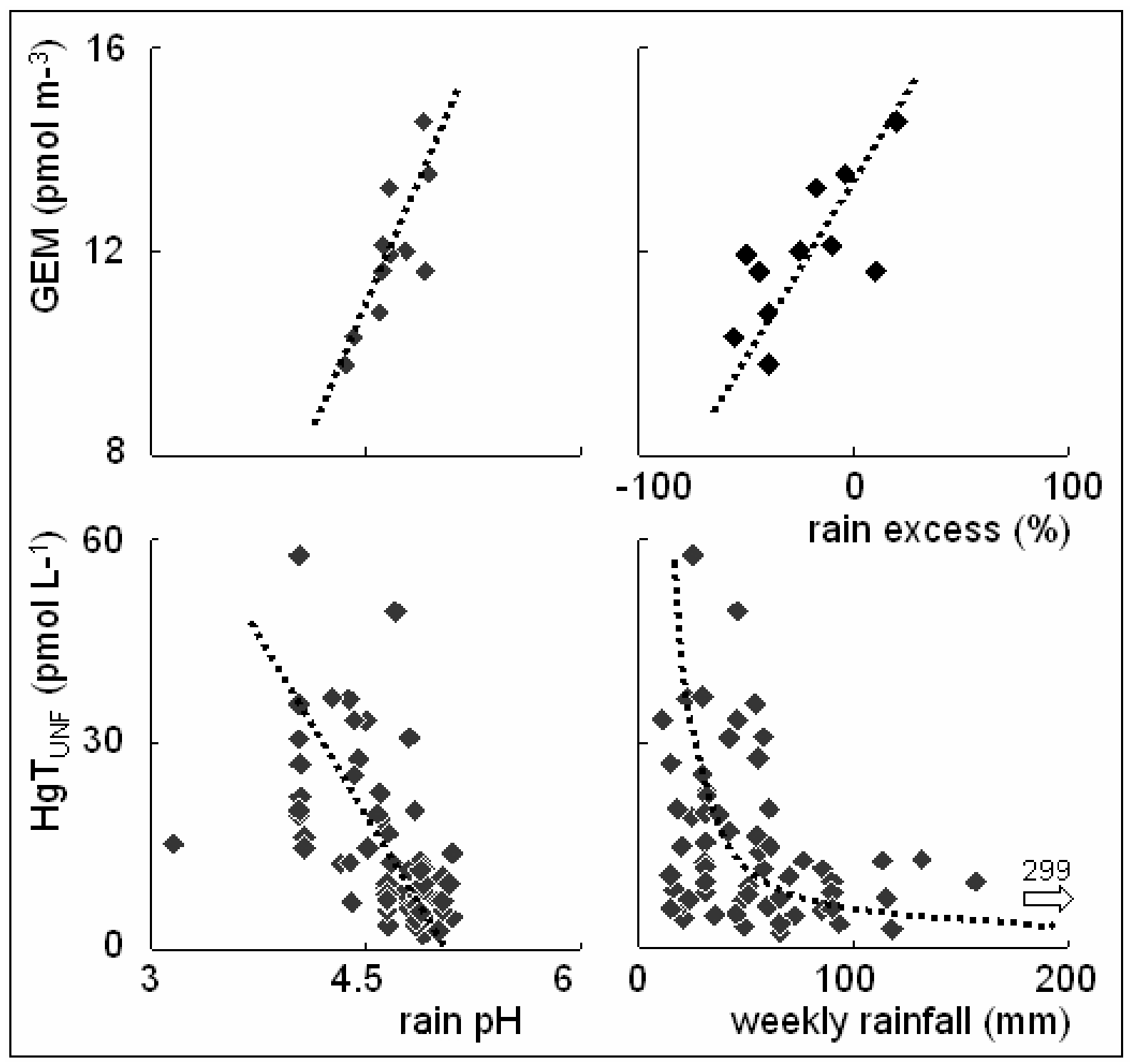

Fig. 6. Upper graphs: monthly GEM concentrations as a function of rain $\mathrm{pH}$ and percentage of rain excess. Lower graphs: weekly rain $\mathrm{HgT}_{\mathrm{UNF}}$ concentrations in relation to rain $\mathrm{pH}$ and deposited amounts. 


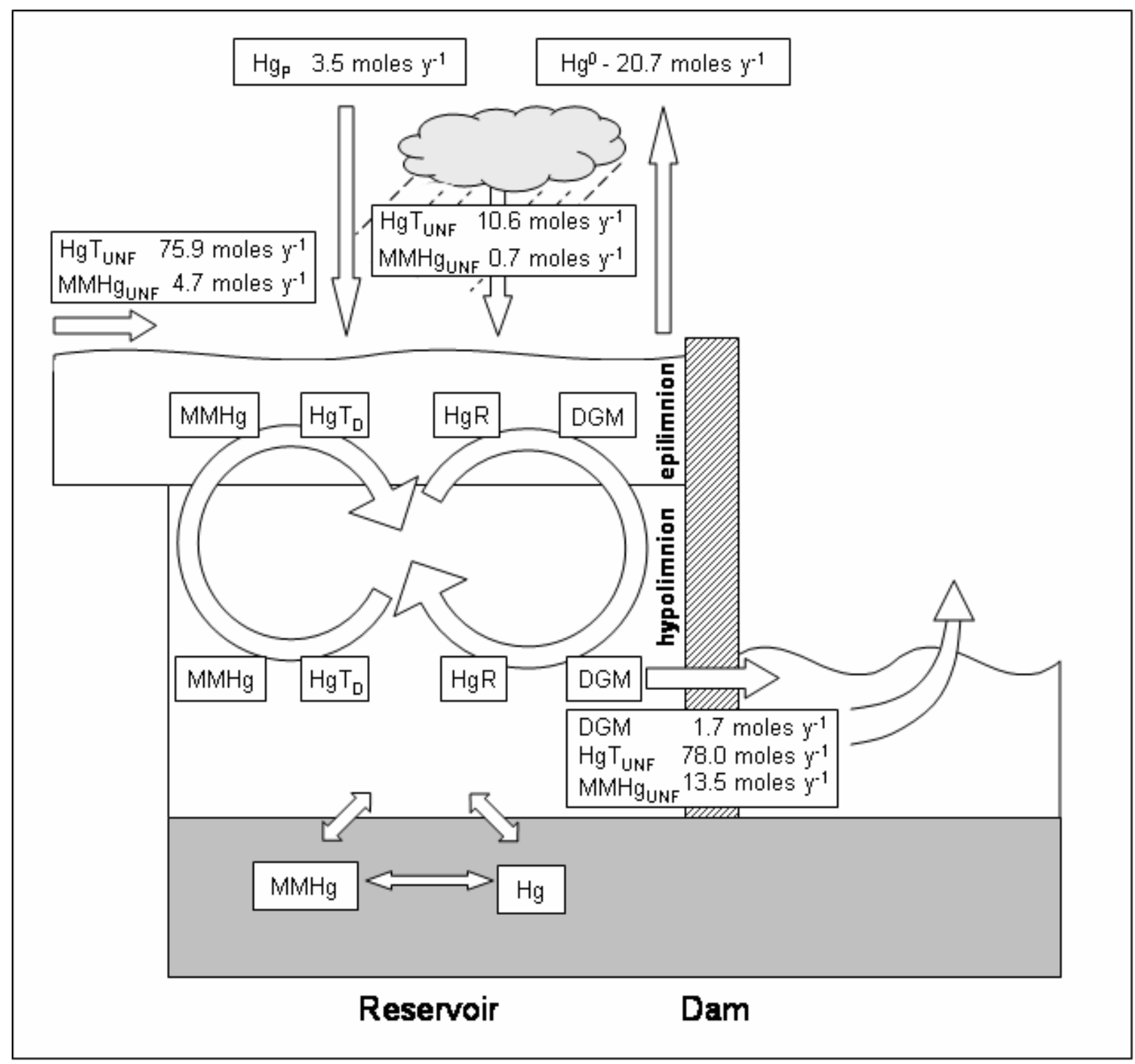

Fig. 7. Mercury budget for the AWI of Petit-Saut reservoir and downstream dam DGM exportations. The whole $\mathrm{HgT}_{\mathrm{UNF}}$ and $\mathrm{MMHg}_{\mathrm{UNF}}$ reservoir budget is given in Muresan et al. (in press). 